\title{
Late Pliocene and Early Pleistocene vegetation history of northeastern Russian Arctic inferred from the Lake El'gygytgyn pollen record
}

\author{
A. A. Andreev ${ }^{1}$, P. E. Tarasov ${ }^{2}$, V. Wennrich ${ }^{1}$, E. Raschke ${ }^{3}$, U. Herzschuh ${ }^{4}$, N. R. Nowaczyk ${ }^{5}$, J. Brigham-Grette ${ }^{6}$, and \\ M. Melles ${ }^{1}$ \\ ${ }^{1}$ Institute of Geology and Mineralogy, University of Cologne, Zülpicherstr. 49a, 50674 Cologne, Germany \\ ${ }^{2}$ Free University Berlin, Institute of Geological Sciences, Paleontology Section, Malteserstr. 74-100, Haus D, \\ 12249 Berlin, Germany \\ ${ }^{3}$ Arctic and Antarctic Research Institute, Bering St. 38, 199397 St. Petersburg, Russia \\ ${ }^{4}$ Alfred Wegener Institute for Polar and Marine Research, Telegrafenberg A43, 14473 Potsdam, Germany \\ ${ }^{5}$ Helmholtz Centre Potsdam, GFZ German Research Centre for Geosciences, Section 5.2 - Climate Dynamics and Landscape \\ Evolution, Telegrafenberg, 14473 Potsdam, Germany \\ ${ }^{6}$ Department of Geosciences, University of Massachusetts, 611 North Pleasant Str., Amherst, MA 01003, USA
}

Correspondence to: A. A. Andreev (aandreev@uni-koeln.de)

Received: 19 July 2013 - Published in Clim. Past Discuss.: 13 August 2013

Revised: 5 March 2014 - Accepted: 28 March 2014 - Published: 22 May 2014

\begin{abstract}
The $318 \mathrm{~m}$ thick lacustrine sediment record from Lake El'gygytgyn, northeastern Russian Arctic cored by the international El'gygytgyn Drilling Project provides unique opportunities for the time-continuous reconstruction of the regional paleoenvironmental history for the past 3.6 Myr. Pollen studies of the lower $216 \mathrm{~m}$ of the lacustrine sediments demonstrate their value as an excellent archive of vegetation and climate changes during the Late Pliocene and Early Pleistocene. About 3.5-3.35 Myr BP, the vegetation at Lake El'gygytgyn, now an area of tundra was dominated by spruce-larch-fir-hemlock forests. After ca. 3.35 Myr BP dark coniferous taxa gradually disappeared. A very pronounced environmental change took place ca. 3.31-3.28 Myr BP, corresponding to the Marine Isotope Stage (MIS) M2, when treeless tundra- and steppe-like habitats became dominant in the regional vegetation. Climate conditions were similar to those of Late Pleistocene cold intervals. Numerous coprophilous fungi spores identified in the pollen samples suggest the presence of grazing animals around the lake. Following the MIS M2 event, larch-pine forests with some spruce mostly dominated the area until ca. 2.6 Myr BP, interrupted by colder and drier intervals ca. 3.043-3.025, 2.935-2.912, and 2.719-2.698 Myr BP. At the beginning of
\end{abstract}

the Pleistocene, ca. 2.6 Myr BP, noticeable climatic deterioration occurred. Forested habitats changed to predominantly treeless and shrubby environments, which reflect a relatively cold and dry climate. Peaks in observed green algae colonies (Botryococcus) around 2.53, 2.45, 2.32-2.305, 2.20 and 2.16-2.15 Myr BP suggest a spread of shallow water environments. A few intervals (i.e., 2.55-2.53, ca. 2.37, and 2.35-2.32 Myr BP) with a higher presence of coniferous taxa (mostly pine and larch) document some relatively shortterm climate ameliorations during Early Pleistocene glacial periods.

\section{Introduction}

The Arctic is known to play a crucial, though not yet completely understood, role in the global climate system (ACIA, 2004). During the last few decades the high Arctic latitudes have experienced significant warming, more dramatic than in other parts of the globe (e.g., Sundqvist et al., 2010, and references therein). Numerical observations show that Arctic temperatures have increased by about $2{ }^{\circ} \mathrm{C}$ since 1961 (IPCC, 2007), and possible scenarios of future climate change and its 


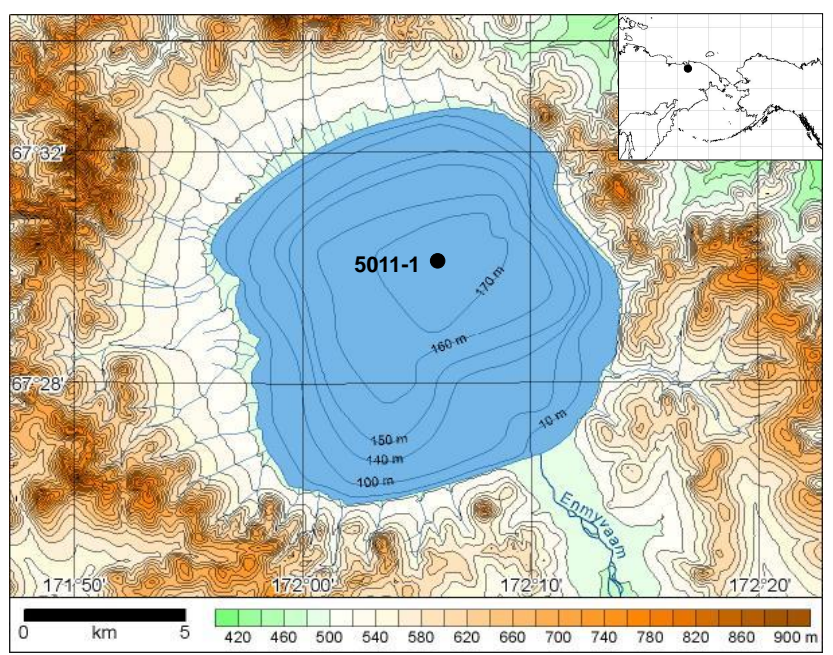

Figure 1. Location of map Lake El'gygytgyn in northeastern Russia (inserted map) with location of the core site.

regional and global consequences remain a major scientific challenge. Reliable climate projections for the Arctic, however, are hampered by the complexity of the underlying natural variability and feedback mechanisms (e.g., Christensen et al., 2007). An important prerequisite for the validation and improvement of climate simulation scenarios is a better understanding of the long-term climate history of the Arctic.

Ice sheet records provide important information on climate history, including former greenhouse gas concentrations, but in the Arctic they only cover the last glacial/interglacial climatic cycle and are restricted to the Greenland ice sheet (e.g., NGRIP Members, 2004). Sedimentary archives from the Arctic Ocean can have a much longer time range, but their paleoenvironmental significance often is hampered by slow, partly discontinuous deposition and poor age control (e.g., Nowaczyk et al., 2001; Moran et al., 2006). In the terrestrial Arctic, continuous paleoenvironmental archives are widely restricted to the Holocene and, in a few cases, to the last glacial/interglacial cycle, due to repeated glaciations that led to disturbance of many of the older sediment sequences (e.g., Andreev et al., 2004, 2009, 2011; Lozhkin et al., 2007; Lozhkin and Anderson, 2011, and references therein). Where older sediments occur, they usually are fragmented and have rather poor age control (e.g., Matthews and Telka, 1997; Ballantyne et al., 2010; Rybczynski et al., 2013).

The first widely continuous Pliocene/Pleistocene record from the entire terrestrial Arctic is now available from Lake El'gygytgyn, which was formed following a meteorite impact 3.58 $\pm 0.04 \mathrm{Myr}$ BP (Layer, 2000) approximately $100 \mathrm{~km}$ to the north of the Arctic Circle in the northeastern Russian Arctic $\left(67^{\circ} 30^{\prime} \mathrm{N}, 172^{\circ} 05^{\prime}\right.$ E, Fig. 1). Within the scope of the El'gygytgyn Drilling Project of the International Continental Scientific Drilling Program (ICDP), three holes were drilled in the center of the lake (Fig. 2) between March

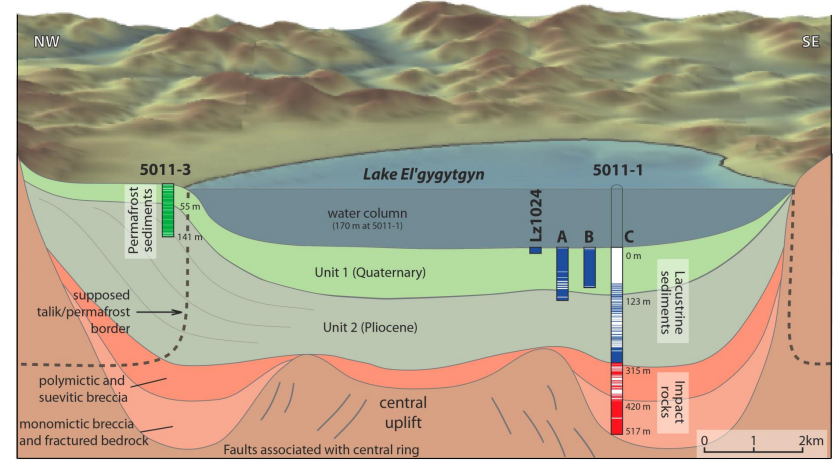

Figure 2. Schematic cross section of the El'gygytgyn basin stratigraphy showing the location of ICDP Sites 5011-1 and 5011-3 (after Melles et al., 2012).

and May 2009, penetrating about $318 \mathrm{~m}$ of lake sediments and $200 \mathrm{~m}$ into the underlying impact rocks (Melles et al., 2011, 2012).

Initial results documenting physical properties from the upper part of the lake sediment succession down to $2.8 \mathrm{Myr}$ BP have provided a complete record of glacial/interglacial change in the Arctic (Melles et al., 2012). According to this study glacial settings with temperatures at least $4{ }^{\circ} \mathrm{C}$ lower than today, allowing perennial lake-ice coverage, first commenced at Lake El'gygytgyn at the Pliocene/Pleistocene boundary about $2.6 \mathrm{Myr}$ BP. This environmental condition gradually increased in frequency from $\sim 2.3$ to $\sim 1.8 \mathrm{Myr}$ BP, eventually occurring within all glacials and several stadials consistent with globally stacked marine isotope records (e.g., Lisiecky and Raymo, 2009). More variable climate parameters were reconstructed for the Quaternary interglacials. Whilst July temperatures and annual precipitation around Lake El'gygytgyn during MIS 1 and MIS 5e were only slightly elevated compared to the modern values, during MIS 11.3 and MIS 31 they were about $4-5^{\circ} \mathrm{C}$ and $300 \mathrm{~mm}$ higher than in the present day (Melles et al., 2012). According to GCM climate simulations the latter values could not readily be explained by interglacial greenhouse gas concentrations and orbital parameters alone; rather they are traced back to feedback mechanisms potentially involving ice sheet disintegrations in the Antarctic (Melles et al., 2012).

A first compilation of data obtained from the lower part of the Lake El'gygytgyn sediment record, from $\sim 3.6$ to $\sim 2.2 \mathrm{Myr} \mathrm{BP}$, was provided by Brigham-Grette et al. (2013). In this study multiproxy evidence suggests extreme warmth and polar amplification during the middle Pliocene, $\sim 3.6$ and $\sim 3.4 \mathrm{Myr} \mathrm{BP}$, when temperatures were $\sim 8{ }^{\circ} \mathrm{C}$ higher but $p \mathrm{CO}_{2}$ is estimated at $\sim 400 \mathrm{ppm}$, comparable with today. Another important finding of BrighamGrette et al. (2013) was that the Pliocene-Pleistocene transition at Lake El'gygytgyn was characterized by stepped cooling events and warmer-than-present Arctic summers until $\sim 2.2 \mathrm{Myr}$ BP, clearly postdating the onset of Northern 
Hemisphere glaciation. Building on the initial studies of Melles et al. (2012) and Brigham-Grette et al. (2013), this paper provides a more complete record and a more detailed discussion of climatical and environmentally driven vegetation changes in the northeastern Russian Arctic between $~ 3.58$ and $\sim 2.15 \mathrm{Myr}$ BP. Their papers are based on the original work presented here.

Lake El'gygytgyn traps pollen from a several thousand square-kilometer source area, thus providing reliable insights into regional and supra-regional millennial-scale vegetation and climate changes. General geographical information concerning the geology, modern climate parameters and vegetation cover patterns in the study area has been well described and discussed in details in many other papers of this special issue (e.g., Andreev et al., 2012; Lozhkin and Anderson, 2013; Tarasov et al., 2013) and therefore is not repeated here. In this publication we focus mainly on the vegetation changes across the time spanned from 3.58 to $2.15 \mathrm{Myr}$ BP.

\section{Data and methods}

The pollen record presented in this study includes a total of 940 pollen spectra from the lower part of ICDP core 5011-1 from Lake El'gygytgyn, below 101.9 m (Fig. 3a-d). Details concerning the preparation method, identification of pollen, spores, and non-pollen-palynomorphs, percentage calculation, and drawing of diagrams are described in Andreev et al. (2012). The age model used for the presentation of pollen record is based on magnetic polarity stratigraphy (Haltia and Nowaczyk, 2014) and the cyclostratigraphy of various climatically controlled sedimentological and geochemical parameters (Nowaczyk et al., 2013). Initial tie points for the age model were derived from major geomagnetic reversals dating back to the early Gauss chron, documented in the cores. The radiometric age of the El'gygytgyn impact at $3.58 \pm 0.04$ Myr BP (Layer, 2000) provided another initial tie point. Fine-tuning of data sequences on biogenic silica, total organic carbon (TOC), tree and shrub pollen percentages, grain-size data, sediment color, $\mathrm{Si} / \mathrm{Ti}$ ratio obtained from X-ray fluorescence (XRF) scanning, and magnetic susceptibility to both the marine oxygen isotope stack (LR04) of Lisiecki and Raymo (2005) and the Northern Hemisphere summer insolation provided by Laskar et at. (2004) stipulated a total of about 600 tie points for the final age model. Further details can be found in Nowaczyk et al. (2013).

To reconstruct relationships between the studied samples and their pollen taxa composition we have used non-metric Multidimensional Scaling (nMDS), an ordination method, which has proved to be a robust technique for data sets with a high beta diversity and high number of zeros (Minchin, 1987). The samples were included in the analysis only if the sum of counted terrestrial pollen and fern spores exceeded 150 grains; the pollen taxa were included if they occur in at least $10 \%$ of samples. The Bray-Curtis coefficient was used to calculate the dissimilarity matrix (Faith et al., 1987). A two-dimensional model was run. To avoid overcrowding only the pollen zone names (placed at respective samples) were plotted. All analyses were carried out in R (R Development Core Team, 2011) using the "vegan package" (Oksanen et al., 2013).

Pollen-inferred vegetation reconstruction performed using the quantitative method of biome reconstruction (also known as the "biomization" approach) helps with the objective interpretation of the pollen data and facilitates datamodel comparison (Prentice et al., 1996). In this approach pollen taxa are assigned to plant functional types (PFTs) and to principal vegetation types (biomes) on the basis of the modern ecology, bioclimatic tolerance, and spatial distribution of pollen-producing plants. The method was tested using extensive surface pollen data sets and regionally adapted biome-taxon matrixes from northern Eurasia (Tarasov et al., 1998) and Beringia (Edwards et al., 2000), and further applied to the mid-Holocene, Last Glacial Maximum (Edwards et al., 2000; Tarasov et al., 2000), and last interglacial pollen spectra (Tarasov et al., 2005).

In the Lake El'gygytgyn project the biome reconstruction approach has been applied to the modern and fossil pollen data sets. For details of the method, assignment of the pollen taxa to biomes, and calculation of the biome affinity scores see Tarasov et al. (2013). In the current paper, quantitative biome reconstruction results obtained for the lower part of the 5011-1 core dated to ca. 3.58-2.15 Myr BP (BrighamGrette et al., 2013; Tarasov et al., 2013) are presented for comparison with the conventional qualitative interpretation of the pollen data.

\section{Results}

\subsection{Results of pollen analysis}

A total of 136 different pollen, spore, and non-pollenpalynomorph types have been found in the studied samples (Fig. 3a-d). Almost no or very few palynomorphs were found in sediments older than $3.575 \mathrm{Myr}$ BP. Only in sediments accumulated between ca. 3.584 and $3.580 \mathrm{Myr} \mathrm{BP}$ is the pollen concentration slightly higher than in underlying and overlying layers. This layer (not presented in Fig. 3) contains few pollen grains of Alnus, Betula, Larix, Myrica, Pinus, Cyperaceae, Poaceae, Ericales, and single grains of Picea, Tilia, Salix, Artemisia, Chenopodiaceae, and Caryophyllaceae. The remains of Botryococcus and Pediastrum green algae colonies are also characteristic for this interval.

The pollen assemblages from 300.74 to $101.9 \mathrm{~m}$ can be subdivided into 58 pollen zones (PZ) based on visual inspection. Single or few pollen grains of Picea, Pinus s/g Haploxylon, Larix, Abies, Tsuga, Betula, Alnus, Poaceae, Cyperaceae, Ericales, Artemisia, Lamiaceae and Sphagnum spores were found in PZ-1 (ca. 3.575-3.531 Myr BP). Pollen 


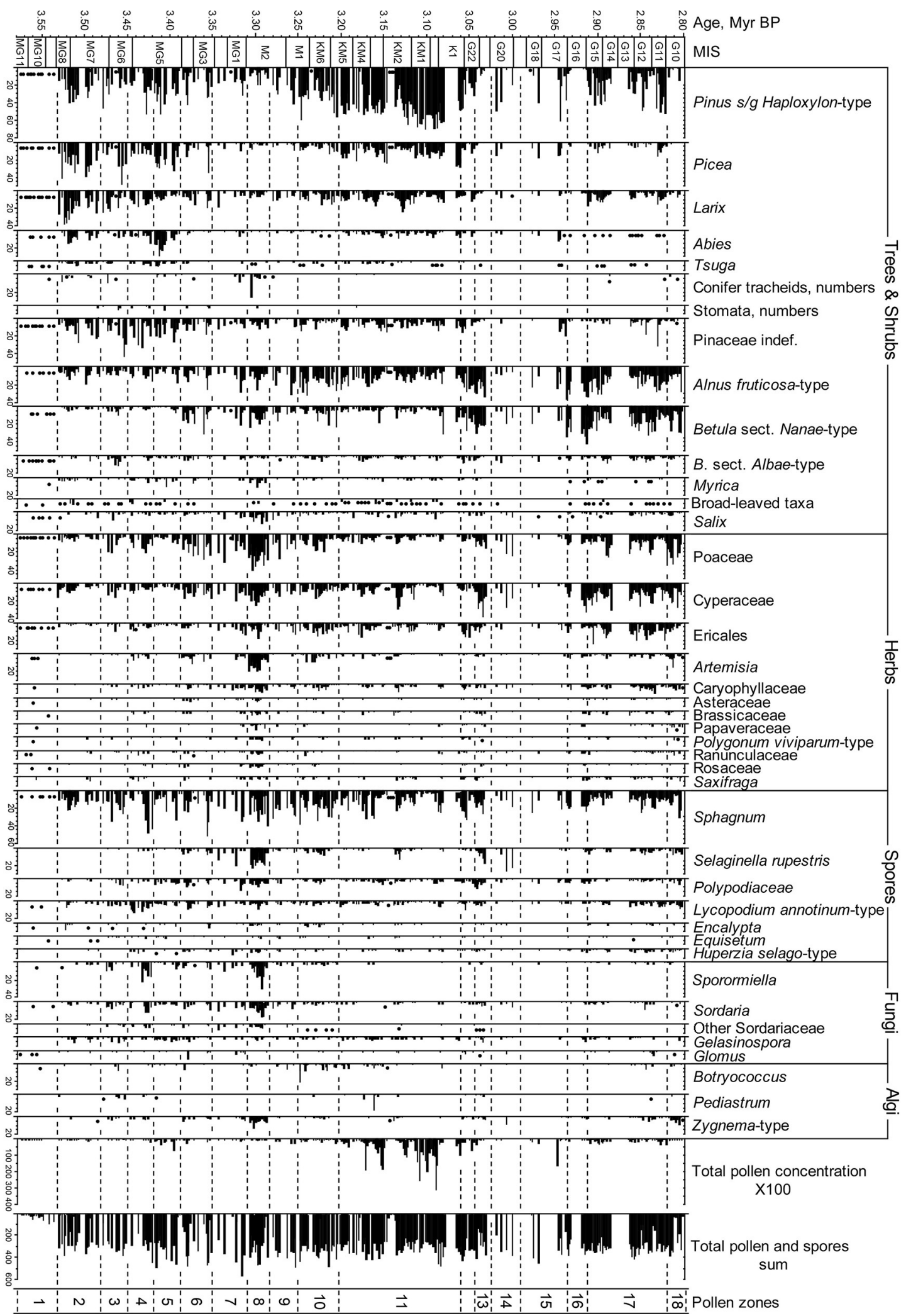

Figure 3a. Percentage pollen, spore, and non-pollen-palynomorph diagram. The most common pollen and spores types between ca. 3.58 and 2.8 Myr BP. 


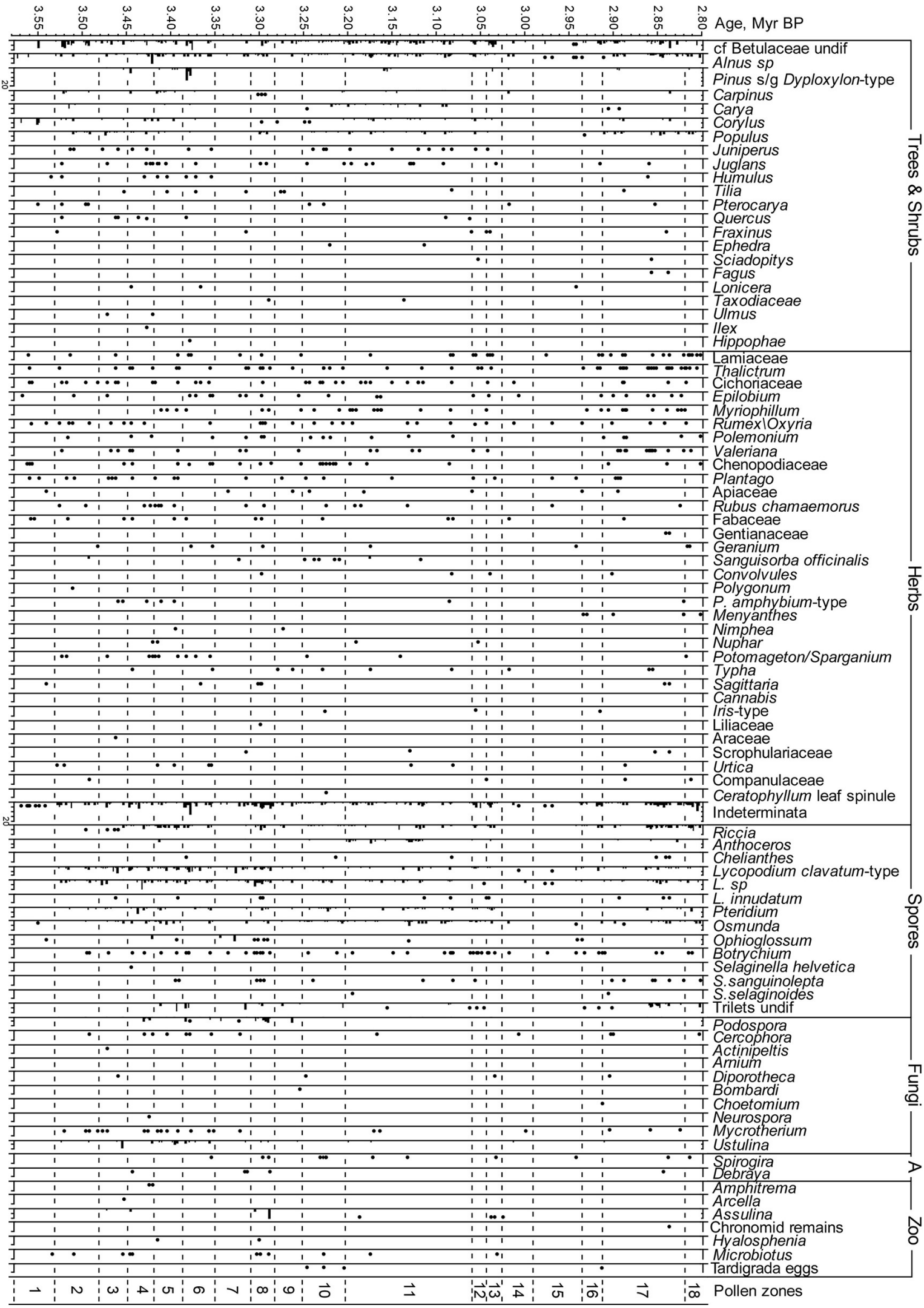

Figure 3b. Percentage pollen, spore, and non-pollen-palynomorph diagram. The minor pollen and spores types between ca. 3.58 and $2.8 \mathrm{Myr}$ BP. 


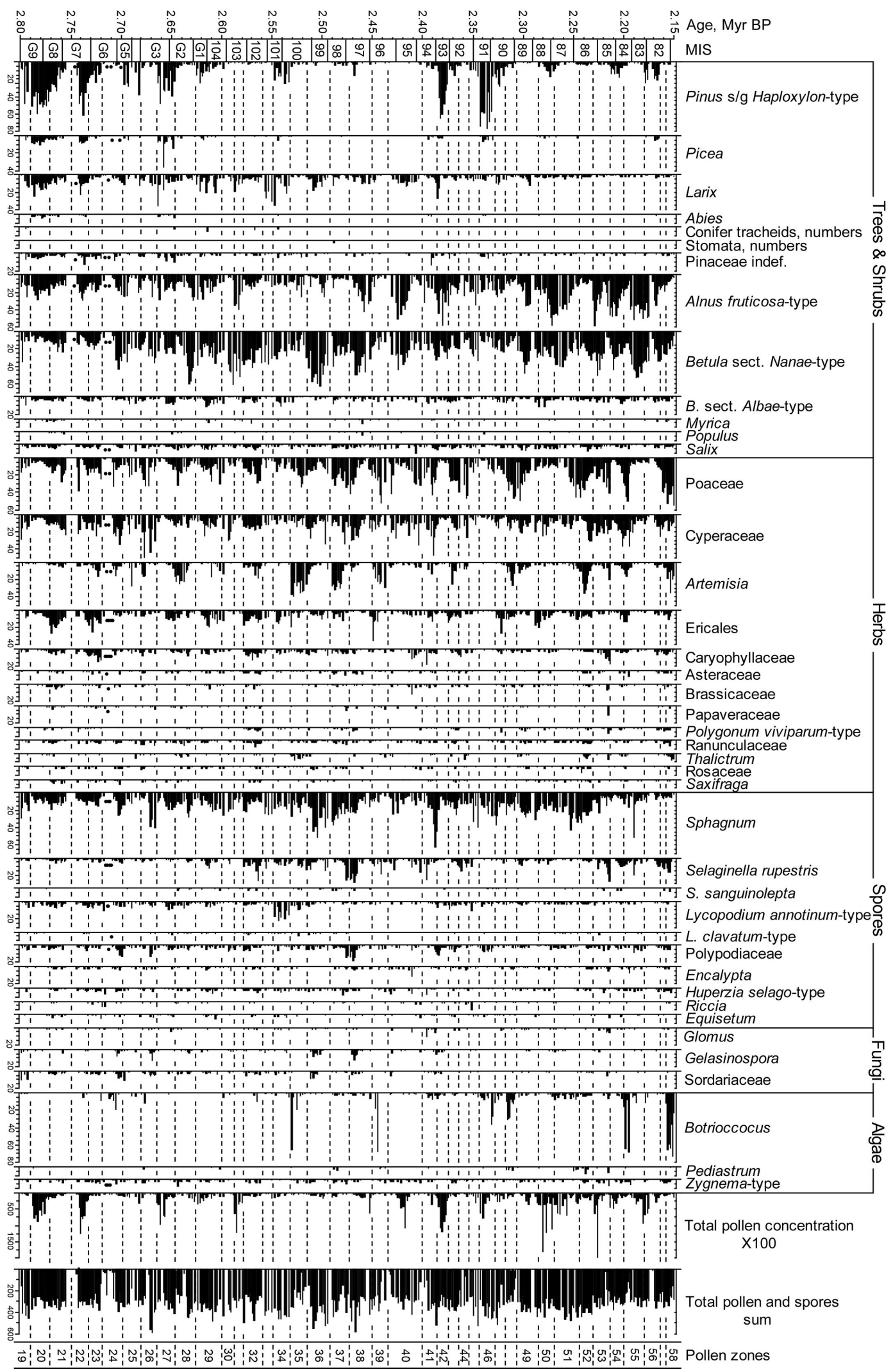

Figure 3c. Percentage pollen, spore, and non-pollen-palynomorph diagram. The most common pollen and spores types between ca. 2.8 and 2.15 Myr BP. 




Figure 3d. Percentage pollen, spore, and non-pollen-palynomorph diagram. The minor pollen and spores types between ca. 2.8 and $2.15 \mathrm{Myr}$ BP. 
concentration gradually increases upwards reaching up to 9090 pollen grains/g in PZ-2 (ca. 3.531-3.481 Myr BP). The spectra for this interval are dominated by Pinus s/g Haploxylon, Picea, Larix/Pseudotsuga, Alnus viridis ssp. fruticosa pollen and Sphagnum spores. Percentages of tree pollen (especially Picea and Larix) are the highest within the studied interval. Rather high contents of Abies pollen and the permanent presence of pollen from some relatively thermophilic taxa, like Tsuga, Carpinus, Corylus, Quercus, Pterocarya, and Carya are also characteristic for PZ-2. Percentages of tree pollen, especially the more thermophilic ones, like Picea, Tsuga, and Abies decreased in the lower part of PZ-3 (ca. 3.481-3.449 Myr BP), while amounts of Poaceae and Cyperaceae pollen significantly increase. A higher presence of Sphagnum, Lycopodium, Polypodiaceae, Sporormiella, and Sordaria spores is also notable. PZ-4 (ca. 3.449-3.419 Myr BP) is characterized by a further decrease in Picea and Abies pollen percentages and higher contents of Sphagnum, Sordaria and Sporormiella spores.

Percentages of Picea and Abies increase again in PZ-5 (ca. 3.419-3.387 Myr BP), while amounts of Poaceae and Cyperaceae pollen, as well as Sphagnum, Sporormiella, and Sordaria spores are significantly decreased. In PZ-6 (ca. 3.3873.350 Myr BP) percentages of Picea and Abies decrease, while amounts of Betula sect. Nanae, Artemisia, Poaceae and Cyperaceae pollen significantly increase. Spores of Selaginella rupestris also become an important component of the pollen assemblages in this zone. PZ-7 (ca. 3.3503.310 Myr BP) is distinguishable by the marked disappearance of Artemisia from the pollen assemblages and a further gradual decrease in coniferous pollen percentages.

PZ-8 (ca. 3.310-3.283 Myr BP) is remarkable because of a distinct decrease in coniferous pollen percentages, while amounts of Poaceae, Cyperaceae, Artemisia, Caryophyllaceae, and another herb pollen, Selaginella rupestris, and coprophilous fungi spores distinctly increase. Pollen concentration, in general, is rather low. PZ-9 (ca. 3.2833.251 Myr BP) is characterized by higher contents of Pinus s/g Haploxylon and Larix pollen, while amounts of Artemisia and Caryophyllaceae pollen, Selaginella rupestris, and coprophilous fungi spores drop significantly.

In PZ-10 (ca. 3.251-3.202 Myr BP) pollen concentrations are distinctly higher (up to 15400 grains/g). This zone is characterized by a further increase in Pinus s/g Haploxylon, Picea, and Larix pollen contents. Contents of Artemisia, Ericales, Caryophyllaceae pollen as well as Selaginella rupestris spores slightly increase as well. The zone is also notable for higher presence of Botryococcus green algae colonies.

Pollen concentration is even higher (up to 315500 grains/g) in PZ-11 (ca. 3.202-3.060 Myr BP). As in PZ-10, the pollen assemblages in PZ-11 are characterized by high concentrations of Pinus s/g Haploxylon, Picea, and Larix pollen. In addition, transparent cysts (Fig. 4) of unclear origin occur in high abundance. These cysts

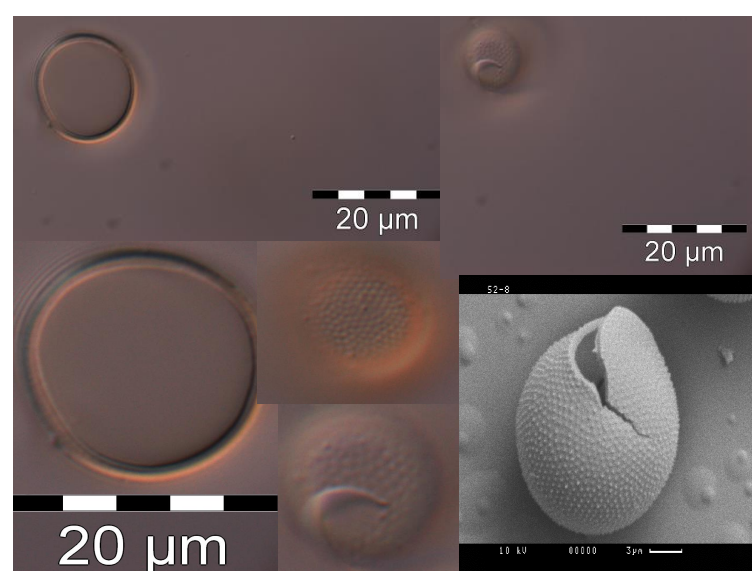

Figure 4. Photos of cysts possibly produced by the so-called snow-algae (species from genera of Chlamydomonas, Chloromonas Haematococcus (Sphaerella), Chlamydomonas, and Chloromonas). Photos by Thomas Leya from Fraunhofer IBMT, Culture Collection of Cryophilic Algae and H. Cieszynski, University of Cologne.

dominate many of the pollen assemblages upwards in the core. PZ-12 (ca. 3.060-3.043 Myr BP) shows an increase in pollen percentages of shrub taxa (Alnus, Betula), while the amounts of coniferous pollen decrease. Alnus, Betula, Poaceae and Cyperaceae pollen, Selaginella rupestris, and Polypodiaceae spores pollen contents increased further in PZ-13 (ca. 3.043-3.025 Myr BP), while coniferous pollen show a further decrease.

PZ-14 (ca. 3.025-2.990 Myr BP) is characterized by rather high contents of Pinus s/g Haploxylon, Poaceae, and Cyperaceae pollen, and Selaginella rupestris spores, while Alnus and Betula ones significantly decrease. PZ-15 (ca. 2.990$2.935 \mathrm{Myr} \mathrm{BP}$ ) is remarkable in the disappearance of $\mathrm{Se}$ laginella spores, a significant decrease in Poaceae and Cyperaceae pollen percentages, and relatively high values of Picea. PZ-16 (ca. 2.935-2.912 Myr BP) is characterized by low contents of coniferous pollen and a further increase in $\mathrm{Al}$ nus, Betula, and Cyperaceae pollen. In PZ-17 (ca. 2.912$2.819 \mathrm{Myr}$ BP) coniferous pollen contents further increase simultaneously with the higher pollen concentration, which reaches 34300 grains/g. PZ-18 (ca. 2.819-2.800 Myr BP) shows a significant decrease in coniferous pollen contents, while Poaceae, Cyperaceae, and Artemisia contents increase. Significant amounts of cysts of Zygnema green algae are also characteristic.

PZ-19 (ca. 2.800-2.790 Myr BP) shows an increase in coniferous pollen contents, while Betula, Poaceae, Cyperaceae, and Ericales pollen decreased. The zone is also notable for the higher presence of coprophilous Sordariaceae but the pollen concentration in this zone is very low. Pollen concentration reaches up to 127130 grains/g in PZ-20 (ca. 2.790-2.771 Myr BP), marked by an increase in coniferous pollen. In PZ-21 (ca. 2.771-2.750 Myr BP) amounts of Pinus s/g Haploxylon pollen and pollen concentration 
gradually decrease, while contents of Cyperaceae, Ericales, and Artemisia pollen, and Selaginella spores increase.

Pollen concentration reaches 136530 grains/g in PZ-22 (ca. 2.750-2.733 Myr BP), which is also characterized by a significant increase in Pinus s/g Haploxylon pollen and a significant reduction in herb percentages. In PZ-23 (ca. 2.733-2.719 Myr BP) the amounts of Pinus s/g Haploxylon pollen gradually decrease and Picea disappear from the spectra, while contents of Cyperaceae, Ericales, and Artemisia pollen, and Selaginella spores increase. The pollen concentration is much lower (up to 5070 grains $/ \mathrm{g}$ ) than in the previous zones. In PZ-24 (ca. 2.719-2.698 Myr BP) Picea and Pinus pollen are almost absent. This zone is also characterized by an increase in Betula and Alnus pollen contents, and a high presence of Botryococcus green algae colonies. PZ25 (ca. 2.698-2.680 Myr BP) differs from the pollen zones below and above by particularly high contents of Pinus and Artemisia pollen.

Pinus pollen disappears from the spectra again in PZ-26 (ca. 2.680-2.665 Myr BP). This zone is also notable for particularly high contents of Gelasinospora, Glomus, and coprophilous fungi spores. PZ-27 (ca. 2.665-2.646 Myr BP) pollen assemblages are characterized by a significant increase in Pinus, Picea, and Larix contents. Pollen concentrations are very high (up to 98850 grains/g). PZ-28 (ca. 2.646$2.626 \mathrm{Myr} \mathrm{BP}$ ) is notable by the disappearance of coniferous pollen, while Artemisia pollen contents increase at the beginning of the zone, and Betula in its upper part. In PZ-29 (ca. 2.626-2.600 Myr BP) Pinus, Larix, and Ericales pollen contents are significantly higher. Percentages of Poaceae and Artemisia pollen increased in the upper part of the zone.

In PZ-30 (ca. 2.600-2.588 Myr BP) coniferous pollen is almost absent. This zone is also characterized by low contents of Alnus pollen, while percentages of Betula and Cyperaceae remarkably increase. Pollen concentration is very low (up to 4750 grains/g). PZ-31 (ca. 2.588-2.578 Myr BP) pollen assemblages differ from PZ-30 based on peaks in Larix and Alnus pollen. In addition, the pollen concentration is much higher (up to 142650 grains/g). PZ-32 (ca. 2.578$2.559 \mathrm{Myr} \mathrm{BP}$ ) is noticeable by a significant increase in Poaceae, Cyperaceae, Ericales, Artemisia, Caryophyllaceae, Ranunculaceae, Brassicaceae, and Asteraceae pollen, and Selaginella spores percentages. Pinus pollen contents are slightly increased as well.

Larix pollen shows a distinct peak in PZ-33 (ca. 2.5592.549 Myr BP), but Pinus disappears from the spectra, while Alnus, Poaceae, Cyperaceae, and other herbs decrease their contents. In PZ-34 (ca. 2.549-2.532 Myr BP) Pinus pollen contents are significantly increased again. This zone is also notable for high contents of Larix pollen and Lycopodium spores. In PZ-35 (ca. 2.532-2.5145 Myr BP) coniferous pollen disappeared again. Large amounts of Artemisia pollen and remains of Botryococcus algae are also notable for this zone. PZ-36 (ca. 2.5145-2.492 Myr BP) is characterized by peaks in the content of Larix and Betula pollen, and Sphag- num spores. PZ-37 (ca. 2.492-2.473 Myr BP) is notable for a peak in Artemisia pollen and high contents of Poaceae.

PZ-38 (ca. 2.473-2.450 Myr BP) is characterized by higher contents of Larix, Alnus, and Betula pollen and Selaginella, Polypodiaceae, Encalypta, and Gelasinospora spores. The pollen concentration is relatively low (up to 42315 grains/g). In contrast, Larix pollen is almost absent in PZ-39 (ca. 2.450-2.435 Myr BP). This zone is also notable for high contents of Poaceae and Artemisia pollen, Selaginella spores and remains of Botryococcus colonies in its lower part. In PZ-40 (ca. 2.435-2.400 Myr BP), pollen concentration is much higher (up to 112300 grains/g). Characteristic for this zone are also higher percentages of Larix, Alnus, and Betula pollen. In PZ-41 (ca. 2.400-2.386 Myr BP) Larix pollen contents decrease, while Pinus pollen appear and contents of Sphagnum spores increased.

PZ-42 (ca. 2.383-2.374 Myr BP) is notable because of peaks in Pinus, Picea, and Alnus pollen, and high pollen concentration (up to 114450 grains/g). In PZ-43 (ca. 2.3742.364 Myr BP)Pinus pollen contents are much lower). In addition, this pollen zone is characterized by peaks in Artemisia and Poaceae pollen as well as Selaginella spores. Coniferous pollen are almost absent in PZ-44 (ca. 2.364-2.354 Myr BP).

PZ-45 (ca. 2.354-2.344 Myr BP) is notable for an increase in Pinus and Larix pollen contents, peaks in Betula and Alnus pollen, and a rather high pollen concentration (up to 32500 grains/g). Relatively high amounts of Botryococcus remains are also characteristic of the zone. In PZ-46 (ca. 2.344-2.328 Myr BP) the high presence of Botryococcus colonies is associated with high percentages of Pinus and a small peak in Picea. In PZ-47 (ca. 2.328-2.318 Myr BP) Pinus pollen contents are much lower, while Ericales pollen contents are higher. Pinus pollen contents are very low in PZ48 (ca. 2.318-2.307 Myr BP), which is also marked by peaks of Artemisia and Poaceae pollen and Botryococcus remains.

Pinus pollen are absent in PZ-49 (ca. 2.307-2.285 Myr BP) but show a small peak in PZ-50 (ca. 2.285-2.269 Myr $\mathrm{BP}$ ), which is also notable because of the higher presence of Ericales pollen and higher overall pollen concentration (up to 183265 grains/g). PZ-51 (ca. 2.269-2.245 Myr BP) is particularly notable for high contents of Betula and Alnus pollen, and Botryococcus remains. In PZ-52 (ca. 2.245-2.230 Myr BP), in contrast, Alnus pollen contents distinctly decrease, while Artemisia pollen, Sphagnum spores, and Pediastrum remains distinctly increase.

In PZ-53 (ca. 2.230-2.214 Myr BP) contents of Betula and Alnus pollen, and spores of Selaginella rupestris increase and pollen concentration is rather high (up to 194165 grains $/ g$ ). In PZ-54 (ca. 2.214-2.200 Myr BP) and PZ-55 (ca. 2.20$2.18 \mathrm{Myr}$ BP) Pinus pollen have small peaks, being almost absent in PZ-56 (ca. 2.180-2.164 Myr BP), but these intervals yield the highest presence of Betula and Alnus pollen. Coniferous pollen is almost absent in PZ-57 (ca. 2.1642.158 Myr BP) and PZ-58 (ca. 2.158-2.150 Myr BP). PZ-58 is also remarkable by peaks in Artemisia, Thalictrum, and 


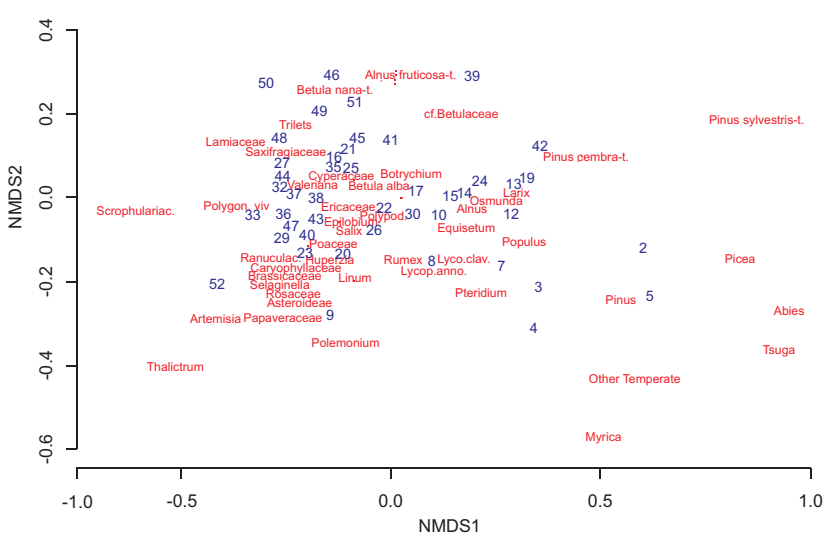

Figure 5. Ordination of revealed pollen spectra. The twodimensional nMDS plot mirrors the similarity among the different pollen zones (i.e., its position represents the centroids of the respective pollen samples) and the major characteristics of their pollen assemblages. A few less important taxa were deleted for clarity.

other herbs pollen, Selaginella rupestris spores as well as remains of Botryococcus.

\subsection{Ordination of revealed pollen spectra}

The two-dimensional nMDS produced a stress value of $16.8 \%$ (stress type 1, weak ties). The nMDS plot (Fig. 5) mirrors the different pollen zones indicating major differences in the species assemblage through time. The first axis separates tree taxa (right side) from herbaceous taxa (left side) placing most shrubs in between. Taxa grouping on the lower right side of the plot (e.g., Tsuga, Abies, Myrica, and temperate broad-leaved taxa) are associated with samples older than 3.355 Myr (PZs 2-7) and summarize elements of temperate and cool mixed or conifer forests. Typical taiga taxa, such as Larix, Pinus, and Alnus, were placed on the upper central and upper right side, however, related pollen zones originating from time slices throughout the pollen record are younger than 3.2 Myr. Dry tundra and steppe elements (e.g., Thalictrum, Artemisia, and Brassicaceae) and typical moist tundra elements and dwarf shrubs (Cyperaceae, Ericales, $B e$ tula, Alnus) are placed in the lower left part and the center of the plot, respectively. This indicates that the inferred pollen taxa relationships reflect their composition in modern vegetation types. A strong change between neighboring pollen zones is evident. This is also obvious from the trend in the plots of the first and second axis through time (Fig. 6).

\subsection{Biome reconstruction}

Biome reconstruction results suggest that six main vegetation types dominated the Lake El'gygytgyn area during the studied interval (Fig. 6). The types include not only boreal grass-shrub vegetation (i.e., tundra and cold steppe), cold deciduous forest, and taiga growing in eastern and north-

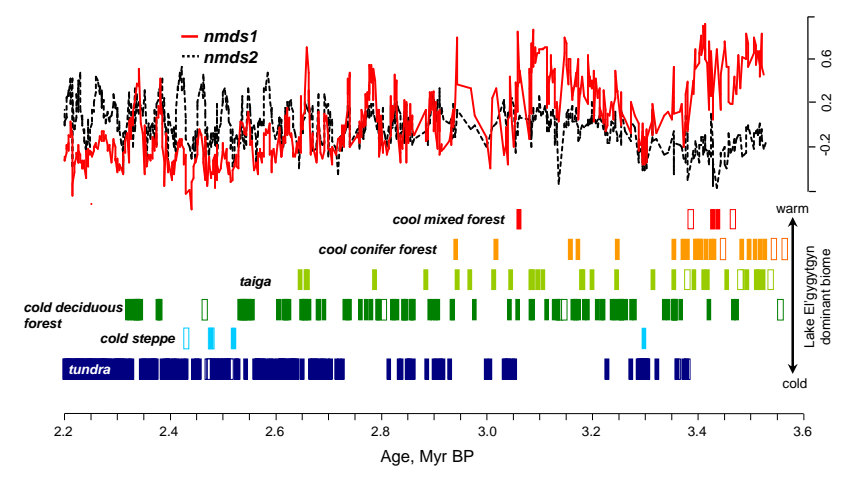

Figure 6. Pollen-based biome reconstruction showing changes in the dominant vegetation type around Lake El'gygytgyn between ca. 3.58 and 2.15 Myr BP. Open squares indicate the biome reconstruction derived from the spectra with low pollen content (i.e., less than 100 terrestrial pollen grains, for details see Tarasov et al., 2013).

eastern Siberia today, but also cool conifer forest and cool mixed forest biomes representing warmer climate regions of the southern Russian Far East. The reconstruction of the latter biomes is particularly noticeable for the lower part of the record (older than $3.370 \mathrm{Myr}$ ), although taiga and cold deciduous forest are also frequently seen between 3.355 and 2.564 Myr BP. Tundra first appeared as a possible dominant vegetation type around $3.367 \mathrm{Myr}$ BP. Two long intervals dominated by arctic tundra vegetation occurred around 3.367 and 3.305-3.273 Myr BP. The biome reconstruction shows a general trend in the vegetation evolution towards colder and drier environments. However, as suggested by the reconstructed fluctuations in the pollen taxa percentages and in the dominant biome scores, this process was not gradual. Biome reconstruction results are further used for the interpretation and discussion of the past environments together with other available records (for details see Tarasov et al., 2013).

\section{Interpretation and discussion}

\subsection{Environmental conditions before 3.6 Myr BP}

There is little data available concerning environmental conditions across Chukotka before 3.6 Myr BP, and these data are obtained from a number of floodplain outcrops in the Enmyvaam River valley, south of the El'gygytgyn Lake basin (Belyi et al., 1994; Minyuk et al., 2006; Glushkova and Smirnov, 2007, and references therein). The sediments are paleomagnetically dated to the Gauss chron (3.6-2.5 Myr BP) by Minyuk et al. (2006). They are overlain by the socalled, chaotic impact horizon, containing spherules, whose origin is connected to the El'gygytgyn impact event (Minyuk et al., 2006; Glushkova and Smirnov, 2007). Hence, it is likely that studied sediments accumulated shortly before the impact event, about 3.58 Myr BP. The sediments contain numerous remains of trees (Larix, Betula, Alnus) and shrubs 
(Pinus pumila, Alnus fruticosa). Moreover, an extinct thermophilic shrub, Aracispermum johnstrupii (Myricaceae) has been found. Pollen assemblages in this interval are dominated by Pinus s/g Haploxylon, Picea, Abies, Betula, and Alnus with rare pollen of more thermophilic taxa like Tsuga, Myrica, Carpinus, Corylus, Quercus, Juglans, Ulmus, Ilex, and Acer (Belyi et al., 1994; Minyuk et al., 2006). Thus, pollen and macrofossil data suggest that forests with pine, spruce, birch, alder, and probably some thermophilic trees were growing in the study area at the end of Gauss Chron, shortly before 3.6 Myr BP. The climate was much warmer than today: mean January temperatures are estimated to be -13 to $-17^{\circ} \mathrm{C}$ (at least $15^{\circ}$ higher than modern) and mean July temperatures 14 to $17^{\circ} \mathrm{C}$ (ca. 8-10 $0^{\circ}$ higher than modern) (Glushkova and Smirnov, 2007).

Other early/middle Pliocene pollen records from Chukotka and northeastern Siberia (e.g., Fradkina, 1983, 1988; Fradkina et al., 2005a, b, and references therein) also document that larch-spruce-birch-alder-hemlock forests were broadly distributed in northeastern Siberia. The early/middle Pliocene pollen and macrofossils records in eastern Beringia (central and northern Yukon, Alaska) show that mixed boreal forests with Pinus, Abies, Larix, Pseudotsuga, Betula, and Alnus also dominated the local vegetation of that region (Schweiger et al., 2011, and references therein). The middle Pliocene pollen record from Lake Baikal shows that mixed coniferous (Pinus, Abies, Larix, Tsuga) forests with some broadleaved taxa (Quercus, Tilia, Corylus, Juglans) were widely spread in southern Siberia (Demske et al., 2002).

\subsection{Environmental conditions before ca. 3.575 Myr BP}

Unfortunately, pollen, spores, and non-pollen-palynomorphs are almost completely absent in the studied lacustrine sediments accumulated before ca. 3.575 Myr BP. The absence of palynomorphs can be explained for two main reasons. First, plant communities as well as fertile soils that existed in the study area before the impact event were likely destroyed in vast distances in and around the crater directly by the event followed by provoked fires. It is difficult to estimate the duration of natural vegetation recovery after such global natural catastrophe. But taking in consideration that not only the vegetation itself, but most probably also fertile soils were completely destroyed around the impact crater, the recovery processes might have taken thousands years. Gradual increase of pollen content in PZ-I (ca. 3.575-3.55 Myr BP), where pollen concentration is extremely low coincides well with such interpretation. However, the second and probably more important reason why we do not find many pollen grains below $300 \mathrm{~m}$ (ca. 3.56 Myr BP) is the high sediment accumulation rate and weak pollen preservation in the lacustrine sediments during the initial phase of the lake formation. The rare pollen grains, which could be wind-transported from the further distance, were most likely mechanically and chemically destroyed because of active processes in the initial lake basin.
Thus, we are limited in the information concerning the initial vegetation succession between the impact event and ca. 3.575 Myr BP. One exception is the short interval (ca. 3.5835-3.5800 Myr BP). Pollen presence in the sediments dated to this interval is notably higher (although pollen concentration remains extremely low, $<300$ grains $/ g$ ). The pollen assemblages probably imply an initial stage of forestation. Forests with alder, birch, larch, possibly with few spruce and lime started to grow in the lake area or in the close vicinity. The relatively numerous remains of Botryococcus and Pediastrum colonies imply that green algae started to colonize the initial lake, which was rather shallow during this interval. It is known that their abundance is greater in sediments deposited in shallow water, especially in small lakes and in the littoral environments of larger lakes (e.g., Guy-Ohlson, 1992; Clausing, 1999; van Geel, 2001).

\subsection{Environmental conditions ca. 3.575-3.531 Myr BP}

A few or single pollen grains of Picea, Pinus s/g Haploxylon, Larix, Abies, Tsuga, Betula, Alnus, Populus, Salix, Poaceae, Cyperaceae, Chenopodiaceae, Ericales, Plantago, Artemisia, Saxifraga, Fabaceae, Cichoriaceae, Rosaceae, Lamiaceae, and spores of Sphagnum and Polypodiaceae were found in the sediments dated to ca. 3.575-3.550 Myr BP (PZ-1, Fig. 3a-b). These pollen data must be carefully assessed for paleoenvironmental interpretation because of the extremely low pollen concentration. Nevertheless, it is notable that the spectra from the bottom part of the zone contain more pollen of potential pioneer taxa, such as Chenopodiaceae, Artemisia, Plantago, Saxifraga, Cichoriaceae, and some others, while tree pollen types are more common in the upper part, which is also characterized by a higher pollen concentration. We suggest that the recovered pollen spectra imply the initial stages of vegetation succession in the lake area: herb-dominated pioneer habitats were more common before ca. 3.55 Myr BP and were gradually replaced over time by woody communities.

\subsection{Environmental conditions ca. 3.531-3.481 Myr BP}

Tree pollen percentages in the sediments deposited 3.5313.481 Myr BP (PZ-2, Fig. 3a) are relatively high. High contents of Abies pollen, the permanent presence of pollen of relatively thermophilic taxa, like Tsuga, and single occurrences of pollen of broad-leaved taxa, like Carpinus, Quercus, Corylus, Carya, Pterocarya, are also characteristic (Fig. 3a, b). It is unlikely that thermophilic broad-leaved taxa might have grown in the lake vicinity, however, the presence of this possibly long-transported pollen points to warm regional and inter-regional climate conditions.

Contents of Larix/Pseudotsuga pollen types are the highest during the studied records and probably imply the dominance of larch in the region. However, it is also possible that these pollen grains are at least partly produced by 
Pseudotsuga (Douglas fir). This suggestion is indirectly supported by very high pollen percentages of spruce and fir (up to 35 and $8 \%$, respectively) as well as the presence of relatively thermophilic taxa pollen.

Pine stands were also numerous in the local vegetation. It is difficult to conclude, whether pollen of Pinus s/g Haploxylon type was produced by tree pines (e.g., modern trees of $P$. sibirica or $P$. koraiensis belonging to this subgenus and growing in Siberia and southern Far East) or by shrub pine (e.g., P. pumila broadly distributed today in northeastern and southern Siberia, Kamchatka, and northern Japan). Because of the high content of Picea and Abies, we assume that a high proportion of the $P$. s/g Haploxylon pollen was produced by tree pine. However, the relatively high content of Alnus fruticosa pollen show that shrub alder was also common in the regional forests and most likely stone pine had also grown in the area, especially at higher elevations. Furthermore, rather high contents of Sphagnum spores imply a broad distribution of open wetlands.

The published Pliocene pollen records from Chukotka and northeastern Siberia (e.g., Fradkina, 1983, 1988; Giterman, 1985; Kyshtymov et al., 1988; Volobueva et al., 1990; Fradkina et al., 2005a and b, and references therein) also document that forests with larch, spruce, birch, alder and hemlock were broadly distributed in the area until at least the end of the Early Pliocene. The relatively high-resolution Pliocene pollen record from Lake Baikal (Demske et al., 2002), which reflects rather favorable environmental conditions between 3.57 and $3.47 \mathrm{Myr} \mathrm{BP}$ is in a good agreement with our data.

Thus, our pollen data along with published environmental records show that climate conditions in the study area at 3.52-3.48 Myr BP (MIS MG7) were the warmest during the studied time intervals. Permafrost was probably still absent in the area, but the first evidence for seasonally frozen sediments in northern Eurasia is suggested at some sites (Fradkina et al., 2005a and b, and references therein). In line with the qualitative interpretations of the regional botanical records, the biome reconstruction (Fig. 6) also indicates boreal forests in the region, and further suggests the predominance of boreal trees and shrubs, as wells as taiga-like vegetation during the colder intervals. In contrast, the presence of cool, temperate trees and shrubs in the vegetation was more pronounced during the warmer intervals, leading to our reconstruction of cool conifer forest at this time.

\subsection{Environmental conditions ca. 3.481-3.419 Myr BP}

A significant decrease in arboreal pollen percentages, especially the more thermophilic taxa like Picea, Tsuga and Abies, at about $3.481 \mathrm{Myr}$ BP (PZ-3, Fig. 3a) suggests harsher environmental conditions than during the previous interval. The beginning of the interval coincides well with MIS MG6. Open habitats (increased Poaceae and Cyperaceae pollen percentages) became more common in the landscape. Significant amounts of coprophilous fungi spores (pri- marily Sporormiella, Sordaria and Podospora) indirectly suggest the presence of numerous large herbivores in the lake vicinity (Baker et al., 2013), thus confirming common open habitats. However, the rather high percentages of Larix/Pseudotsuga and Pinus pollen indicate that pine-larchDouglass fir (?) forests were broadly distributed in the area. A slight decrease in Picea and Abies pollen percentages after ca. 3.449 Myr BP (PZ-4, Fig. 3a) coinciding with an increase in Poaceae, Caryophyllaceae, and Artemisia pollen as well as Lycopodium, Sphagnum, Sordaria, and Sporormiella spores, implies a trend towards deforestation and a more open landscape.

Thus, we assume that although coniferous (mostly pine, larch and spruce) forests dominated the regional vegetation between ca. 3.481 and 3.419 Myr BP, open and partly treeless grassland habitats became more common across the landscape especially after ca. 3.449 Myr BP. Climatic conditions became cooler and probably wetter (increase in Sphagnum spore contents) than during the previous interval, but dryer episodes also regularly occurred. The suggested environmental changes might be associated with climate fluctuations documented in the Kutuyakh suite sediments broadly distributed in northeastern Russia (including Chukotka), and paleomagnetically dated between 3.4 and $1.8 \mathrm{Myr}$ (Laukhin et al., 1999; Fradkina et al., 2005a, b). However, the age control of these records is very poor, making a direct comparison impossible. Generally, pollen-based reconstructions yielded larch-birch-spruce forests for the early Kutuyakh, tundra vegetation for the middle Kutuyakh, and open larchbirch forests-tundra during the late Kutuyakh for northeastern Siberia (Giterman, 1985; Fradkina et al., 2005a, b). Environmental records from northern Yakutia also show a gradual vegetation change towards tundra and the expansion of larchbirch forests during the Kutuyakh interval (Grinenko et al., 1998).

The unconsolidated fluvial-lacustrine deposits that accumulated in the Enmyvaam River valley above the chaotic impact horizon yield pollen spectra, which suggest a mosaic of vegetation types by open grasslands and coniferous forests with birch and alder trees (Glushkova and Smirnov, 2007). Belyi et al. (1994) reconstructed birch and alder shrubs alternating with wetlands along rivers during the Kutuyakh interval. However, these regional records are very fragmented and poorly dated, and thus cannot be directly compared with our record or with the records mentioned above. In contrast, the lacustrine pollen data from Lake Baikal (Demske et al., 2002), showing drier and colder episodes around 3.47 and 3.43 Myr BP are relatively comparable with the environmental fluctuations inferred from the Lake El'gygytgyn record.

The biome reconstruction (Fig. 6) displays greater variation in the vegetation communities. As in the earlier part of the record, cool conifer and taiga forests are often seen for this time interval, but colder phases are marked by the predominance of cold deciduous forest. The cool mixed forest reconstruction (found twice in the middle part of this 
interval) suggests the presence of cool, temperate broadleaved taxa somewhere close to the lake, and thus, implies warmest climate of the whole record.

\subsection{Environmental conditions ca. 3.419-3.387 Myr BP}

The pollen spectra, which accumulated 3.419-3.387 Myr BP (PZ-5, Fig. 3a, b) imply the increased presence of spruce and especially fir in the area, indicative of relatively warm climate conditions. The remains of a fir twig (identified by V. R. Filin, Moscow State University) found in the sediments dated to about 3.4 Myr BP directly confirms the presence of fir in the vicinity of the lake. Coniferous forest with spruce, pine, and fir dominate the regional vegetation. Higher presence of Myrica pollen and pollen of long-distancetransported broad-leaved taxa (Carpinus, Corylus, Juglans, Tilia) also support a warmer climate. Another important peculiarity of the PZ-5 pollen assemblages is the permanent presence (sometimes up to $3 \%$ ) of Gelasinospora spores. Gelasinospora species are mainly fimicolous, but also carbonicolous and lignicolous. Their spores reach the highest frequencies in highly decomposed buried peats, which contain burned woody remains and charcoals (van Geel, 2001). Therefore, rather the high content of their spores may point to a higher frequency of fire events.

According to Late Pliocene records from the Canadian Arctic coniferous forest (mostly Picea and Pinus) likely extended to the coast of Arctic Ocean (Schweiger et al., 2011). Reconstructed mean annual temperatures were $19^{\circ} \mathrm{C}$ warmer than today and mean summer growing temperatures were approximately $+14{ }^{\circ} \mathrm{C}$ warmer than today (Ballantyne et al., 2010). These estimations are close to the climate reconstructions for PZ-5 based on our pollen record (Brigham-Grette et al., 2013).

\subsection{Environmental conditions ca. 3.387-3.310 Myr BP}

Significant decreases in Picea and Abies pollen percentages and increases in dwarf Betula and especially herbs (mainly Poaceae, Cyperaceae and Artemisia) after ca. 3.387 Myr BP (PZ-6, Fig. 3a) reflect significantly colder and drier climate conditions at Lake El'gygytgyn. Selaginella rupestris (indicator of dry environments) spores became an important component of the pollen assemblages as well. The revealed spectra indicate that pine-larch forests dominated the vegetation, but open, herb-dominated habitats were also common around the lake. The beginning of environmental changes coincides well with MIS MG4.

After 3.35 Myr BP (PZ-7, Fig. 3a, b) a further disappearance of tree pollen from the spectra accompanied by an increase in herbs and spores indicate that environmental conditions became much cooler. The onset of these environmental changes coincides well with MIS MG2. An increase in Selaginella rupestris content documents very dry climate conditions. The disappearance of Artemisia indicates that steppe-like habitats with Artemisia were less common than before. Decreased spruce and dwarf Betula pollen contents along with the increased contents of coprophilous fungi spores suggest the presence of treeless habitats in the area. Significant amounts of coprophilous fungi spores (primarily Sporormiella, Sordaria and Podospora) in the sediments suggest the presence of grazing animals in the lake vicinity and also confirm that open habitats were common in the study area.

The biome reconstruction (Fig. 6) shows the first appearance of tundra as a vegetation type in the study region, thus confirming notable climate deterioration. However, boreal vegetation continuously dominated the landscape.

These pollen assemblages can be compared with pollen spectra in till sediments of northeastern Chukotka. These spectra reflect significant cooling at about 3.5-3.2 Myr BP during the so-called Zhuravlinean glaciation, the first local alpine glaciation, when mountain glaciers extended into the lowlands (Laukhin et al., 1999; Fradkina et al., 2005b). However, the age control on these sediments is very poor. Pollen-based climate reconstructions using the socalled information-statistical method (Klimanov, 1984) suggest mean July and January temperatures of ca. 14 to $18^{\circ} \mathrm{C}$ and about -25 to $-18^{\circ} \mathrm{C}$, respectively, and annual precipitation in the range of 425 to $500 \mathrm{~mm}$ (Laukhin et al., 1999). Generally, these estimations correlate rather well with climate reconstructions based on our pollen record. However, according our reconstructions, temperatures of the warmest month between 3.387-3.310 Myr BP were not higher than $15^{\circ} \mathrm{C}$ and annual precipitation ranged between 300 and $600 \mathrm{~mm}$ (Brigham-Grette et al., 2013; Tarasov et al., 2013).

\subsection{Environmental conditions ca. 3.310-3.283 Myr BP}

Low percentages of coniferous pollen in PZ-8 (Fig. 3a, b) and increased percentages of Poaceae, Cyperaceae, Artemisia, Caryophyllaceae, Brassicaceae, Ranunculaceae, Rosaceae, and other herb pollen, as well as Selaginella rupestris and coprophilous fungi spores reflect a mostly treeless tundraand steppe-like vegetation during this interval, which is synchronous with MIS M2. Although very pronounced changes in the pollen assemblages point to dry and cold climate conditions similar to those during the Late Pleistocene, relatively high pollen contents of Alnus, Betula, Pinus, and Larix show that tree and shrubby vegetation also survived in the area, probably in more protected localities. Relatively high contents of cysts of Zygnema (green algae) in the lake sediments point to shallow-water environments, likely a result of lake level lowering. High contents of Sphagnum spores indicate the existence of wetlands in the lake vicinity.

Large amounts of coprophilous fungi spores indirectly imply a permanent presence of numerous grazing herds (e.g., bison, mammoth, horse) around the lake, thus confirming that open habitats became broadly distributed in the study 
area. Interestingly, this episode corresponds to the so-called Mammoth paleomagnetic subchron.

The climate of the M2 interval at Lake El'gygytgyn coincides well with colder and drier climate conditions found in the Lake Baikal record (Demske et al., 2002). Generally, the pollen assemblages imply the likely mosaic character of the vegetation. The M2 interval might also be linked to the final (coldest) stage of the Zhuravlinean glaciation recorded in eastern Chukotka that is supposed to have occurred 3.53.2 Myr BP (Laukhin et al., 1999; Fradkina et al., 2005b).

The existing terrestrial and marine records also provide consistent evidence for the intensification of continental glaciations in the Northern Hemisphere during the middle Pliocene (e.g., Matthiessen et al., 2009; de Schepper et al., 2013, and references therein). Therefore, we suggest dry and cold environments reconstructed from PZ-8 pollen assemblages to be simultaneous with the coldest stage(s) of the Zhuravlinean glaciation traced in eastern Chukotka. Environmental records from eastern Beringia also indicate more open forest conditions and the existence of permafrost (ice wedge casts) at about $3 \mathrm{Myr}$ (Schweiger et al., 2011, and references therein). In the biome reconstruction (Fig. 6) this interval is marked by a continuous dominance of tundra and an absence of forest biomes.

\subsection{Environmental conditions ca. 3.283-3.202 Myr BP}

A distinct increase of coniferous pollen percentages (mostly Pinus s/g Haploxylon) at about 3.283 Myr BP (PZ-9, Fig. 3a) implies the dominance of pine stands in the region of Lake El'gygytgyn. The pollen spectra also contain Larix and Picea suggesting that pine-larch-spruce forests dominated the area between ca. 3.283 and 3.251 Myr BP. Large amounts of $\mathrm{Al}$ nus fruticosa pollen suggest that shrub alder was the most common shrub in the local forests. Pollen of Pinus s/g Haploxylon might have been at least partly produced by shrub pine ( $P$. pumila), which today covers higher elevations in southeastern Siberia that have deep snow. However, a better subdivision of Pinus pollen produced by trees and by shrubs is not possible.

Coniferous pollen contents gradually increased in PZ10 (ca. 3.251-3.202 Myr BP), but this pollen assemblage contain rather large amounts of Alnus, Poaceae, and other herb pollen, such as Artemisia, Ericales, Caryophyllaceae, Chenopodiaceae as well as Selaginella rupestris and coprophilous fungi spores. The assemblage shows that open herb-dominated habitats became more common again in the landscape than during the previous interval. This suggests the occurrence of a drier climate interval, which presumably coincides with MIS KM6. Our data also coincide well with colder and drier climate conditions revealed from the Baikal record around 3.26 Myr BP (Demske et al., 2002).
Rather high amounts of coprophilous fungi spores (mostly Sordaria) in the lake sediments are notable until ca. 3.202 Myr BP inferring the presence of numerous grazing animals, although they probably occurred in reduced abundance compared to the MIS M2 interval. Small peaks of Botryococcus green algae colonies also found in the sediments dating between ca. 3.251 and 3.202 Myr BP suggest a shallower water environment in the lake.

\subsection{Environmental conditions ca. 3.202-3.060 Myr BP}

After ca. 3.202 Myr BP (PZ-11, Fig. 3a) spruce again became a more important component in the local forests, suggesting further climate amelioration. A significant decrease of Poaceae and Cyperaceae pollen and Sphagnum spores content, alongside the disappearance of coprophilous fungi spores from the pollen assemblages suggest that open habitats decreased in the landscape. A higher presence of Myrica pollen and pollen of long-distance-transported broad-leaved taxa, such as Carpinus, Corylus, Juglans, and Tilia (Fig. 3b) also points to warmer climate conditions during the interval.

Climate reconstructions based on our pollen record show that the temperature of the warmest month between 3.202 and $3.060 \mathrm{Myr}$ might have reached $16-17^{\circ} \mathrm{C}$ (BrighamGrette et al., 2013; Tarasov et al., 2013). Thus, the interval, which coincides well with the PRISM interval (Dowsett et al., 2010) was not as warm or wet as it was between 3.58 and 3.40 Myr (PZs 1-5). However, it is also notable that our reconstructed temperatures are ca. $1.5^{\circ} \mathrm{C}$ warmer than those suggested by multi-model simulations of the Pliocene Model Intercomparison Project (Haywood et al., 2013).

PZ-11 interval may at least partly coincide with the top of the Pliocene Beaufort formation at Meighen Island in the Canadian Arctic, which was dated to 3.2 Myr. This formation contains two- and five needle pines with beetle assemblages suggesting minimum and maximum season temperatures +10 to $+15^{\circ} \mathrm{C}$ warmer than today (Elias and Matthews, 2002; Schweiger et al., 2011). Boreal forests at this time stretched from 60 to $80^{\circ} \mathrm{N}$ and included pine taxa, which are absent in the modern Alaska and Yukon forests (Matthews and Telka, 1997).

In the Lake El'gygytgyn sediments deposited since ca. 3.087 Myr BP numerous small (ca. $12-15 \mu \mathrm{m}$ in diameter) globose and transparent macrofossils, often with an Sshaped furrow occur (Fig. 4). This type has been described from alpine lacustrine and peaty sediments by Klaus (1977) as so-called Coccus nivalis. The concentration of these cysts here reaches more than 300000 per $\mathrm{cm}^{3}$ in Weichselian sediments, but their numbers drastically decreased in the early Holocene deposits (Klaus, 1977; Schultze, 1984). The cysts in Lake El'gygytgyn are also similar to type 128B of van Geel (2001, and references therein), but spines are missing in our specimens.

The cysts are most likely hypnozygote spores of algae from Chlamydomonas genus, which commonly produce 
thick-walled cysts under environmentally unsuitable conditions (e.g., van den Hoek et al., 1995). Such hypnozygote spores may have been produced by the so-called snow-algae from Chlamydomonas or Chloromonas genera (T. Leya, Fraunhofer IBMT, 2011 and R. Below, University of Cologne, personal communications, 2013).

Snow-algae are common today in snow and ice fields in arctic and alpine regions around the world (e.g., Kol, 1968; Müller et al., 1998; Gorton and Vogelmann, 2003; Remias et al., 2010, and references therein). Many Chlamydomonas species are also common under aquatic conditions. Their cells and resting hypnozygotes are commonly responsible for the blood-red color seen on surfaces of snow fields and at the bottoms of desiccated rock pools and bird baths. Müller et al. (1998) reported that small (ca. $10 \mu \mathrm{m}$ ), round cysts were the most common type in snow surface samples from Svalbard. Moreover, such cysts are very common in modern pollen samples collected from surface ice and snow fields in the coastal areas of western Siberia (e.g., Vasil' chuk and Vasil'chuk, 2009, 2010) or at the North Pole (Ukraintseva et al., 2009). Unfortunately, the identification of such small, round cells in the pollen slides is problematic and they are often reported in the pollen records as spores of green mosses (the so-called Bryales). Such Bryales are often reported in palynological assemblages of Quaternary deposits in the Russian literature being interpreted as green moss spores; however, their real origin remains uncertain.

Thus, we regard it as rather likely that the numerous cysts found in the El'gygytgyn lacustrine sediments were probably produced by snow algae. Snow algae are known to be well adapted to a rather narrow temperature range around $0^{\circ} \mathrm{C}$ with optimum growth conditions below $10^{\circ} \mathrm{C}$ (Müller et al., 1998). The presence of numerous hypnozygotes in the El'gygytgyn sediments younger than ca. 3.087 Myr BP (above $163.5 \mathrm{~m}$ core depth) therefore may indirectly reflect a longer persistence of large snow fields in the study area during the cyst-dominated intervals. Air temperatures are supposed to have varied between 0 and $10^{\circ} \mathrm{C}$ during their growing season in spring.

At the end of PZ-11 at about 3.08 Myr BP, corresponding to the paleomagnetic Kaena subchron (Nowaczyk et al., 2013), an increase in dwarf Betula and herb pollen contents occurred simultaneously with a drastic decrease of pollen concentration suggesting a climate deterioration. At the same time, a peak of herbs (especially Artemisia) is also documented in the pollen record from Lake Baikal (Demske et al., 2002).

\subsection{Environmental conditions ca. 3.060-2.990 Myr BP}

Coniferous pollen gradually decreased in the sediments deposited after ca. 3.06 Myr BP (PZ-12, Fig. 3a), while the content of shrub taxa (Betula sect. Nanae, Alnus fruticosa) and Ericales increased. Such changes point to a climate deterio- ration in the region. The onset of deteriorating environmental changes coincides well with MIS G22.

After ca. 3.043 Myr (PZ-13, Fig. 3a) higher contents of shrub taxa (Betula sect. Nanae, Alnus fruticosa), Poaceae and Cyperaceae pollen, Selaginella rupestris and Polypodiaceae spores appear, while tree pollen percentages are significantly reduced. These changes are interpreted to reflect the broader distribution of open treeless habitats in the study area, thus suggesting colder and drier climate conditions. Similar climatic conditions coincide with the Baikal pollen record based upon an increase in spores of Selaginella rupestris around 3.03 Myr BP (Demske et al., 2002).

Around 3.025 Myr BP, contents of Betula and Alnus shrub pollen significantly decrease in the spectra (PZ-14, Fig. 3a), while Pinus, Picea and Larix increase. Hence, pollen spectra document that pine-larch forests with some spruce trees were the common vegetation type between ca. 3.025 and 2.990 Myr BP. However, high contents of Poaceae and Cyperaceae pollen as well as Selaginella rupestris spores show that open treeless habitats were also common in the study area during this interval, coinciding with the MIS G20. These changes point to intervals of climate deterioration consistent with colder and drier conditions corroborated by higher contents of coprophilous fungi (Sordaria). Open treeless habitats, are suggested with grazing mammals more common than earlier intervals.

\subsection{Environmental conditions ca. 2.990-2.80 Myr BP}

The interval ca. 2.990-2.924 Myr BP (PZ-15, Fig. 3a) is remarkable based upon the disappearance of Selaginella and coprophilous fungi spores from the pollen assemblages, and significant decreases in Poaceae, Cyperaceae contents, while Picea shows relatively high contents. Thus, the pollen assemblages imply that forests with pines, larch, spruce, and probably some fir became dominant in the regional vegetation suggesting a significant amelioration of environmental conditions that coincides well with MIS G17. Rather favorable climate conditions before ca. 2.94 Myr BP are documented in the Baikal pollen record as well (Demske et al., 2002).

Lower contents of coniferous pollen and a further increase in Alnus, Betula, Poaceae, Cyperaceae, and Ericales pollen after ca. 2.935 (PZ-16, Fig. 3a) suggest a further climate deterioration. Later, between 2.924 Myr and 2.912 Myr BP, pine and spruce probably completely disappeared from the vegetation, suggesting that climate conditions became even worse. The PZ-16 interval coincides well with MIS G16. Generally, the revealed deterioration of climate conditions is simultaneous with the onset of an intensified Northern Hemisphere glaciation during the Late Pliocene, which is dated between 3.0 and 2.9 Myr BP (Matthiessen et al., 2009, and references therein).

After 2.912 Myr BP (PZ-17, Fig. 3a) coniferous and Cyperaceae pollen percentages further increase suggesting that climate conditions became wetter and warmer again 
across the western Arctic. The climate amelioration is also suggested by an increased presence of long-distance transported pollen by some thermophilic broadleaved taxa (PZ17, Fig. 3b). The start of the interval coincides well with MIS G15. Pine-larch forest with some spruce dominated the regional vegetation. With an understory of forests in and around the lake alder, birch, hearth shrubs and grass-sedge communities were also common.

A drastic decrease in Pinus and Picea pollen percentages ca. 2.82 Myr BP, along with increases in willow, Caryophyllaceae, Artemisia, Saxifraga and other herb percentages suggests drier and colder climatic conditions during that period. This short-term climate deterioration coincides well with MIS G10 and a phase of reduced Tsuga-Picea moist forests that are documented in the Baikal pollen record around 2.892.68 Myr BP (Demske et al., 2002).

\subsection{Environmental conditions ca. 2.800-2.733 Myr BP}

Climate conditions again became wetter and warmer ca. 2.8 Myr BP (PZ-19, Fig. 3c) as reflected by increases in coniferous, Cyperaceae and Ericales pollen, and Sphagnum spores percentages. The revealed changes coincide well with MIS G9. Larch forests with shrub pine and alder dominate around the lake. However, the relatively high presence of coprophilous Sordariaceae spores in the spectra indirectly points to the presence of numerous grazing animals in the lake vicinity, and, therefore suggests that more open grasssedge-herb communities were also common. A further increase in coniferous (including spruce) and Alnus pollen contents ca. 2.79 Myr BP (PZ-20, Fig. 3c) simultaneous with very high pollen concentrations in the spectra point to more favorable climate conditions during MIS G9.

A remarkable decrease in coniferous pollen percentages ca. 2.771 Myr BP (PZ-21, Fig. 3c), along with an increase in percentages of Poaceae, Cyperaceae, Artemisia, Ericales, and Caryophyllaceae pollen and Selaginella spores suggests that local conditions responded to an interval of drier and colder climate conditions. This climate deterioration might coincide with MIS G8. A further increase in coniferous and Alnus pollen after ca. 2.75 Myr BP (PZ-22, Fig. 3c) shows that larch forests with shrub pine some spruce, and alder dominated around the lake suggesting that climate conditions became again more favorable.

\subsection{Environmental conditions ca. 2.733-2.698 Myr BP}

Coniferous pollen concentrations gradually decreased from the pollen assemblages accumulated after $2.733 \mathrm{Myr}$ BP (PZ-23, Fig. 3c), while the content of Betula, Poaceae, Caryophyllaceae, and especially Artemisia, increased. These changes suggest that forests disappeared from the vegetation, while open steppe- and tundra-like habitats became more common in the area. The implied climate deterioration towards much drier and colder conditions coincides well with
MIS G6. It may also coincide with the buildup of regional ice caps in northwestern Canada and an early Cordilleran ice sheet, which certainly took place between 3.00 and $2.58 \mathrm{Myr}$, but most likely started at 2.74 Myr (Duk-Rodkin et al., 2010).

Climatic deterioration culminated between 2.719 and $2.698 \mathrm{Myr}$ BP, as indicated by the absence of Pinus and Picea pollen, while at the same time shrub Alnus and dwarf Betula increased and contents of herb pollen remain high (PZ-24, Fig. 3c). Such pollen assemblages imply that open herb and dwarf shrub communities dominated the vegetation, reflecting very cold and dry climate conditions. A significant climate deterioration after $2.71 \mathrm{Myr} \mathrm{BP}$ is also reconstructed from the pollen record of Lake Baikal, in particular by the nearly complete disappearance of hemlock pollen (Demske et al., 2002). Rather numerous remains of Botryococcus green algae colonies in the sediments from Lake El'gygytgyn suggest shallower environments in the lake.

\subsection{Environmental conditions ca. 2.698-2.665 Myr BP}

Between 2.698 and 2.680 Myr BP (PZ-22; Fig. 3c) a return of pine forests in the local vegetation is suggested by the rather high presence of Pinus pollen which indicates some amelioration of the climate conditions that may coincide with MIS G5. However, high contents of Artemisia pollen also suggest the presences of a rather dry climate. Larch forests with stone pine, shrubby alder and birch alternated with open, steppe-like habitats.

Further disappearance of Pinus and Larix pollen from the spectra between 2.680 and 2.665 Myr BP (PZ-23, Fig. 3a) coincides with the MIS G4, indicating a further deterioration of the climate. Open tundra and steppe-like herb communities dominated the local vegetation. Higher contents of Gelasinospora, Glomus, and coprophilous fungi spores suggest the presence of grazing animals around the lake during this interval and disturbed soils. Dry forest types also expanded in the Baikal region after 2.68 Myr BP (Demske et al., 2002).

\subsection{Environmental conditions ca. 2.665-2.626 Myr BP}

A drastic increase in Pinus, Picea, Larix, and Ericales pollen contents between 2.665 and 2.646 Myr BP (PZ-27, Fig. 3c) reflects the dominance of larch-spruce-pine forest in the Lake El'gygytgyn region. We infer that the climate conditions became much warmer and wetter.

The interval ca. 2.645-2.626 Myr BP (PZ-28, Fig. 3c) is notable because of the disappearance of coniferous pollen from the spectra, pointing to a significant climate deterioration during MIS G2. Open steppe-like herb communities dominated the local vegetation. Moreover, the increase of Gelasinospora and coprophilous fungi spore suggest the presence of numerous grazing animals around the lake. The higher presence of Artemisia pollen at the beginning of the interval suggests rather dry climate conditions. 
Concentrations of Betula sect. Nanae, Alnus fruticosa, and Cyperaceae pollen, and Sphagnum spores show a significant increase after 2.635 Myr BP, which implies that birch and alder shrubs were common in the region, thus hinting at much wetter climate conditions. This interval can be correlated with the onset of the most extensive Cordilleran ice sheet in northwestern Canada, which is dated to 2.64 Myr BP (Hidy et al., 2013).

\subsection{Environmental conditions ca. 2.626-2.600 Myr BP}

Around 2.626 Myr BP (PZ-29, Fig. 3c) the pollen spectra suggest a return of pine and larch to the area, presumably as a consequence of some climate amelioration coinciding with MIS G1. This suggestion is confirmed by an increase in Ericales pollen. The climate conditions became much warmer and wetter than during the previous interval. However, rather high pollen contents of Artemisia, Caryophyllaceae, Brassicaceae, and other herb as well as Selaginella spores, which appear after ca. 2.612 Myr BP, suggest drier environmental conditions. Based on the pollen assemblages we can assume that the regional vegetation was characterized by larch forests with stone pine, shrubby alder and birch, alternating with open steppe- and tundra-like habitats.

The upper boundary of the warm interval coincides rather well with the paleomagnetic Gauss-Matuyama boundary (Melles et al., 2011, 2012; Haltia and Nowaczyk, 2014; Nowaczyk et al., 2013). Thus, vegetation changes showing a transition from interglacial environmental conditions to glacial ones are reflected rather well at the PliocenePleistocene (MIS 104/MIS 103) boundary. The biome reconstruction suggests a broad spectrum of vegetation communities representing arctic herb/shrub as well as boreal tree/shrub plant functional types (Tarasov et al., 2013). Tundra, cold deciduous forest, and taiga are reconstructed suggesting a larger variability in the regional climate.

\subsection{Environmental conditions ca. 2.600-2.532 Myr BP}

Between 2.600 and 2.588 Myr BP (PZ-30; Fig. 3c) coniferous pollen is almost completely absent from the spectra. Alnus fruticosa pollen contents and total pollen concentration drop significantly as well, while the concentrations of Betula sect. Nanae and Cyperaceae increase. The spectra suggest that dwarf shrubs became dominant in the regional vegetation as a consequence of serious climate deterioration at the onset of the Pleistocene (MIS 103). Climate conditions became cooler and significantly drier compared with the previous interval.

In the Lake Baikal area, a remarkably reduction of forested areas took place after 2.61 Myr BP, when steppe environments later showed a strong expansion (Demske et al., 2002). In eastern Beringia pollen and macrofossils also demonstrate that Pinus and Picea species disappeared or were greatly reduced in the local vegetation after ca. $2.6 \mathrm{Myr} \mathrm{BP}$, while grasses and other herbaceous taxa increased (Schweiger et al., 2011, and references therein).

Between 2.588 and 2.578 Myr BP (PZ-31, Fig. 3c) increases in Larix and especially Alnus pollen contents suggest that open larch forests with shrub alder, tundra- and steppelike communities dominated in the region. A significant increase in pollen concentration also points to climate amelioration in this interval.

Slightly less favorable climate conditions between 2.578 and 2.559 Myr BP (PZ-29, Fig. 3c) are suggested by a slight decrease in Larix and Alnus pollen contents. Simultaneous and significant increases in Poaceae, Cyperaceae, Ericales, Artemisia, Caryophyllaceae, Ranunculaceae, Brassicaceae, and Asteraceae pollen and Selaginella spore percentages also document rather dry and cold climate conditions. Furthermore, the relatively high content of coprophilous fungi spores in this interval implies the presence of grazing animals around the lake. A small peak in Botryococcus around 2.56 Myr BP may suggest shallow water environments in the lake.

The environmental changes between 2.600 and 2.559 Myr BP might have been also associated with the beginning of the second, so-called Okanaanean glaciation that occurred in eastern Chukotka at the beginning of the Pleistocene around 2.5 Myr BP (e.g., Laukhin et al., 1999; Fradkina et al., 2005 b). In contrast to the Zhuravlinean glaciation, which was centered towards the ocean shore, the Okanaanean glaciation developed further to the west (Laukhin et al., 1999). However, age control on the till sediments attributed to the Okanaanean glaciation is rather poor.

Pollen-based climate estimations for the same period conducted by Laukhin et al. (1999) yielded mean July temperatures on order of $14^{\circ} \mathrm{C}$, mean January temperatures ranging between -20 and $-28^{\circ} \mathrm{C}$, and annual precipitation - between 400 and $450 \mathrm{~mm}$. However, according our reconstructions, temperatures of the warmest months between 2.600 and $2.559 \mathrm{Myr} \mathrm{BP}$ were probably not higher than $12-13^{\circ} \mathrm{C}$ and annual precipitation ranged between 250 and $350 \mathrm{~mm}$ (Brigham-Grette et al., 2013; Tarasov et al., 2013). Moreover, taking in consideration the poor age control of the sediments studied by Laukhin et al. (1999) it is rather difficult to compare the reconstructed climate parameters.

Approximately 2.559 Myr BP (PZ-33, Fig. 3c) the Larix pollen concentrations significantly increased in the spectra again. The interval is additionally characterized by lower contents of Alnus, Poaceae, Cyperaceae, and other herbs. Such pollen assemblages suggest that larch forest again became more wide-spread around the lake, thus pointing to a slightly more favorable (wetter and probably warmer) climate. This suggestion is also supported by a small increase in Sphagnum spores. The interval coincides well with beginning of MIS 101.

A peak in Pinus pollen and rather high Larix contents between ca. 2.549 and 2.532 Myr BP (PZ-34, Fig. 3c) documents a further climate amelioration during MIS 101. Larch 
forests with stone pine, shrubby alder, and birch in the understory dominated the vegetation. Large amounts of $L y$ copodium spores in the spectra show that they also were important elements in the local vegetation.

\subsection{Environmental conditions ca. 2.532-2.473 Myr BP}

Coniferous pollen drastically decreased again between 2.532 and 2.515 Myr BP (PZ-35, Fig. 3c). High contents of Artemisia, Thalictrum and Poaceae pollen mark broadly distributed steppe-like habitats, thus suggesting very dry climate conditions. Numerous remains of Botryococcus algae colonies imply abundant shallow-water environments in the lake.

The pollen assemblages that have accumulated between 2.515 and 2.492 Myr BP (PZ-36, Fig. 3c) suggest that larch forest with dwarf birch in the understory dominated the area. High contents of Sphagnum spores may be traced back to a paludification and wetter soil conditions. The revealed climate amelioration coincides well with MIS 99. The contemporaneous Baikal pollen record also suggests that environmental conditions at about $2.5 \mathrm{Myr} \mathrm{BP}$ were relatively favorable, facilitating the growth of moisture-dependent fir and even broadleaved taxa in the area (Demske et al., 2002).

Between ca. 2.492 and 2.473 Myr (PZ-37, Fig. 3c) larch stands again played only a minor role in the vegetation. High contents of Artemisia and Poaceae pollen imply that steppe habitats became more common around the lake. This interval is simultaneous with MIS 98.

\subsection{Environmental conditions ca. 2.473-2.400 Myr BP}

Contents of trees and shrubs are rather low in the pollen assemblages accumulated between 2.473 and $2.465 \mathrm{Myr}$ BP (low part of PZ-38, Fig. 3c). Very high contents of Selaginella, Polypodiaceae, Encalypta, and Gelasinospora spores and a small peak in Artemisia in this interval also points to rather harsh environmental conditions. Gradually, we see increased concentrations of Larix, Alnus, and Betula pollen upwards in the zone suggesting some climate amelioration coinciding with MIS 97. We assume that larch forests with shrubby birch and alder in the understory grew around the lake between 2.465 and 2.450 Myr BP. It is possible that shrubby habitats dominated at higher elevations.

Between 2.450 and 2.435 Myr BP (PZ-39, Fig. 3c) larch and shrub alder stands were probably completely absent in the lake area. As suggested by the high contents of Poaceae and Artemisia pollen, and Selaginella spores, open, steppelike communities were broadly distributed instead. An increase in the abundance Artemisia pollen and a remarkable peak in Botryococcus algae colony remains point to a short-term event of particularly dry climate, leading to increased shallow-water environments in Lake El'gygytgyn after 2.45 Myr BP. At the same time, coinciding well with the beginning of MIS 96, dry forests and steppe communities reached broad distribution and maximum herb diversity in the Baikal region (Demske et al., 2002).

The return of larch forests with shrubby birch and alder in the understory took place between 2.435 and 2.400 Myr BP (PZ-40, Fig. 3c) as reflected by much higher percentages of Larix, Alnus, and Betula pollen.

\subsection{Environmental conditions ca. 2.400-2.354 Myr BP}

A gradual increase in Pinus pollen percentages starting around 2.400 Myr BP (PZ-41, Fig. 3c) documents that stone pine stands increasingly appeared in the lake vicinity or relatively close by, although larch forests with shrubby birch and alder in the understory still dominated around the lake. This suggests that the climate became slightly warmer than before. In addition, a higher presence of Sphagnum spores points to a drastic increase in moisture ca. 2.385 Myr BP corresponding to the end of the PZ-41 interval. However, relatively high amounts of Botryococcus remains found in the sediments reflect shallow environments in the lake during the interval. This can best be explained by flooding of the rather flat parts of the crater due to a lake-level rise.

A drastic increase in Pinus pollen percentages and pollen concentration between about 2.386 and 2.374 Myr BP (PZ42, Fig. 3c) indicates that dense stone pine communities dominated the vegetation in the area during this period. However, shrub alder and birch stands were also common. The vegetation cover was probably very similar to the modern northern larch taiga in northeastern Siberia, where numerous stone pine, birch, and alder shrubs composed the understory and dominated higher elevations. The relatively high presence of Picea pollen may suggest the fact that spruce also grew in the crater or in its close vicinity. Consequently, climate conditions during PZ-42 became wetter and warmer than during PZ-41. This interval is simultaneous with MIS 93.

Starting ca. 2.374 Myr BP (PZ-43, Fig. 3c) percentages of Pinus pollen again became much lower implying a significant decrease in pine stands in the lake area, but larch probably still grew at the lake vicinity. Shrub alder also partly disappeared from the local plant communities. Simultaneous peaks in Artemisia, Poaceae, and Selaginella rupestris show that open steppe habitats again became dominant in the region. Thus, climate conditions are inferred to have been much drier than before which coincides well with beginning of MIS 92.

Between ca. 2.364 and 2.354 Myr BP (PZ-44, Fig. 3c), coniferous and shrub alder stands might have completely disappeared from the lake vicinity. Instead, open steppe communities dominated the vegetation. This implies climate conditions even drier and also significantly colder than before. This climate deterioration coincides well with MIS 92. 


\subsection{Environmental conditions ca. 2.354-2.289 Myr BP}

Increases in Pinus and Larix pollen content and peaks in shrub Betula and Alnus between 2.354 and 2.344 Myr BP (PZ-45, Fig. 3c) suggest that the vegetation cover became similar to the northern limit of modern northern larch taiga and/or tundra-forest zones in northeastern Siberia, where open larch stands alternate with shrubby stone pine, alder, and birch communities. Climate conditions were much wetter and warmer than during the previous period.

The amount of Botryococcus colonies were relatively high in the sediments deposited between ca. 2.344 and $2.328 \mathrm{Myr}$ BP (PZ-46, Fig. 3c), suggesting the persistence of shallowwater environments in the lake. Very high percentages of $\mathrm{Pi}$ nus, a small peak in Picea, and the presence of Larix pollen in the same interval suggest that the area was dominated by larch taiga with some spruce and dense stone pine communities in the understory. Shrub alder and birch stands were also broadly distributed around lake.

Successively decreasing Pinus pollen contents between 2.328 and $2.318 \mathrm{Myr}$ BP (PZ-47 of the Fig. 3c) imply a gradual disappearance of pine from the vegetation. However, larch forest with shrub alder, dwarf birch, and probably some stone pines dominated the area until ca. $2.318 \mathrm{Myr}$ BP (PZ-48). The simultaneous increase in Ericales pollen contents shows that heath communities were exceptionally broadly distributed around the lake during that time. Environmental conditions obviously were drier between ca. 2.318 and 2.307 Myr BP (PZ-48), as evidenced by increases in Artemisia and Poaceae pollen contents. Steppe coenoses were common in the area. The presence of numerous remains of Botryococcus algae colonies suggests the existence of widespread shallow-water environments in the lake. Gradual climate deterioration suggested in PZ-47 and PZ-48 coincides well with MIS 90.

From ca. 2.307 to $2.289 \mathrm{Myr}$ BP (PZ-49, Fig. 3c) pine was probably completely absent in the regional vegetation. However, a rather higher presence of Larix, Alnus, and Betula pollen in the spectra, along with decreases in herb pollen contents suggest that larch forest with shrub alder and dwarf birch in understory became more broadly distributed around the lake. Climate at this time was wetter and warmer than during the previous time interval coinciding well with MIS 89.

A comparable, presumably coincident climate change is deduced from palynological data in northwestern Canada and Alaska, which shows that floristic elements required to form northern boreal forests and tundra ecosystems were first established in the region about 2.3 Myr (e.g., White et al., 1997, and references therein).

\subsection{Environmental conditions ca. 2.289-2.230 Myr BP}

Pinus pollen shows a small peak in the Lake El'gygytgyn sediments deposited at the upper part of PZ-50 (2.289-
2.269 Myr BP, Fig. 3c). The zone also contains evidence for a higher presence of Ericales and single pollen of Picea. Such changes point to some climate amelioration, which may coincide with beginning of MIS 87. Larch forests with shrub alder, dwarf birch, and probably few stone pines dominated the vegetation in the region. Rare spruce might grow in more protected habitats.

Stone pine completely disappeared again between ca. 2.269 and 2.245 Myr BP (PZ-51, Fig. 3c), while birch and alder stands increased at the beginning of this interval coinciding with the end of MIS 87, but gradually decreased later on at the beginning of MIS 86. Relatively high contents of Botryococcus remains in PZ-51 suggest the existence of shallow-water environments in the lake.

Environmental conditions again became worse between ca. 2.245 and 2.230 Myr BP (PZ-52, Fig. 3c), when larch, birch, and especially alder shrub stands were further reduced. Peaks in Artemisia and Poaceae pollen contents suggest a broader distribution of steppe habitats under significantly drier climate conditions. This indicates that environmental conditions became drier and probably colder coincident with glacial conditions during MIS 86. Relatively high contents of Botryococcus and Pediastrum algae colony remains and cysts of Zygnema-type in the sediments point to shallow-water environments, likely as a result of lake-level lowering. However, high contents of Sphagnum spores document that boggy habitats were also common around the lake.

\subsection{Environmental conditions ca. 2.230-2.150 Myr BP}

Between ca. 2.230 and 2.214 Myr BP (PZ-53, Fig. 3c) drastically increased Betula and Alnus pollen concentrations and the disappearance of Artemisia are thought to reflect shrubby communities that again became more common in the local vegetation. Climate conditions were probably wetter and warmer than during the PZ-52 interval coinciding well with the beginning of MIS 85. Nevertheless, an increase in $\mathrm{Se}$ laginella rupestris spores indicates that the climate was rather harsh.

A small peak of Pinus pollen between 2.214 and 2.200 Myr BP (PZ-54, Fig. 3c) implies that stone pine might have grown in the region, thus pointing to a further climate amelioration, which might be correlated with the end of MIS 85 . This suggestion is confirmed by peaks in Alnus and partly Betula, and a simultaneous decrease in herb pollen content. Climate conditions were probably slightly warmer than during the PZ-53 interval.

Pine disappeared again from the regional vegetation after 2.2 Myr BP (PZ-55, Fig. 3c) implying a further climate deterioration. Peaks in Artemisia and Poaceae pollen contents at the beginning of the zone suggest a broader distribution of steppe habitats under significantly drier climate conditions. This suggests that environmental conditions became drier and probably colder coincident with MIS 84. A simultaneous peak in Botryococcus algae colony remains points to 
shallow-water environments, likely as a result of lake level lowering. Generally, birch and alder shrubs dominated the area. Larch stands might have survived in more protected habitats, such as river valleys.

Between 2.180 and 2.164 Myr BP (PZ-56, Fig. 3c) increased amounts of Pinus pollen suggest that stone pine might have migrated back into the region. Simultaneous decreases in herb pollen contents indicate a reduction of open steppe- and tundra like communities, presumably as a result of wetter climate conditions. However, birch and alder shrub communities dominated the local vegetation as during the previous interval.

The pollen assemblages accumulated between 2.164 and 2.158 Myr BP (PZ-57, Fig. 3c) suggest that shrubs (especially stone pine) were significantly reduced in the vegetation cover, while open steppe- and tundra-like communities became broadly distributed. However, the presence of single Larix pollen grains indicates that larch were likely surviving in more protected habitats (e.g., river valleys). The inferred vegetation changes suggest a deterioration of the climate conditions.

Further increases in Poaceae, Artemisia, Thalictrum, and other herb pollen after $2.158 \mathrm{Myr}$ BP (PZ-58, Fig. 3c) point to enhanced deforestation of the lake vicinity and very dry and cold climate conditions. Numerous remains of Botryococcus algae colonies found in the sediments points to extensive shallow-water environments in Lake El'gygytgyn.

\section{Conclusions}

The results of this study demonstrate that the Pliocene/Pleistocene pollen record of Lake El'gygytgyn is an excellent archive of vegetation changes on the Chukchi Peninsula in the northeastern Siberian Arctic as a result of local, regional and global climate fluctuations. The record reflects well the main paleoenvironmental fluctuations in the region during the late Pliocene since ca. 3.56 Myr BP. Spruce-larch-fir-hemlock forests grew in the area about 3.52-3.35 Myr BP. Climate conditions in the study area were the warmest between 3.5-3.4 Myr BP. Most pronounced environmental changes (appearance of tundra- and steppelike habitats) are revealed at about ca. 3.31-3.28 Myr BP and around 2.71 to $2.60 \mathrm{Myr} \mathrm{BP}$, pointing to cold and dry conditions.

Open treeless vegetation dominated during the early Pleistocene. However, relatively warm intervals with larch forest and stone pine growing around the lake occurred about 2.550-2.535, 2.395-2.365, and 2.355-2.320 Myr BP.

Drastic peaks in green algae colonies (Botryococcus) coinciding with peaks in Artemisia and Poaceae pollen around $2.532,2.45-2.32,2.32-2.305,2.2$ and $2.16-2.15 \mathrm{Myr}$ BP point to enhanced shallow-water conditions in the lake that can be associated with dry climate intervals.
Acknowledgements. Funding for the drilling operation at Lake El'gygytgyn in 2008/09 was provided by the International Continental Scientific Drilling Program (ICDP), the US National Science Foundation (NSF), the German Federal Ministry of Education and Research (BMBF), Alfred Wegener Institute (AWI), GeoForschungsZentrum Potsdam (GFZ), the Russian Academy of Sciences Far East Branch (RAS FEB), the Russian Foundation for Basic Research (RFBR), and the Austrian Federal Ministry of Science and Research (BMWF). The Russian GLAD 800 drilling system was developed and operated by DOSECC Inc. and LacCore, at the University of Minnesota, handled curation of the lake sediment cores retrieved. Financial support for the palynological analyses was provided by the BMBF (grant 03G0642) and the German Research Foundation (DFG; grant ME 1169/24). The work of PT was financed via the Heisenberg program of the DFG (grant TA 540/5). Special thanks are due to Dr. T. Leya from Fraunhofer IBMT, Culture Collection of Cryophilic Algae, and Dr. R. Below and H. Cieszynski, University of Cologne, for the identification and photography of cysts in the sediment record. We are also thankful two anonymous reviewers and B. Fréchette for the suggestions and comments that helped to improve the paper.

Edited by: D.-D. Rousseau

\section{References}

ACIA: Impacts of a warming Arctic: Arctic Climate Impact Assessment. Cambridge University Press, Cambridge, 2004.

Andreev, A. A., Grosse, G., Schirrmeister, L., Kuzmina, S. A., Novenko, E. Yu., Bobrov, A. A., Tarasov, P. E., Kuznetsova, T. V., Krbetschek, M., Meyer, H., and Kunitsky, V. V.: Late Saalian and Eemian paleoenvironmental history of the Bol'shoy Lyakhovsky Island (Laptev Sea region, Arctic Siberia), Boreas, 33, 319-348, 2004.

Andreev, A. A., Grosse, G., Schirrmeister, L., Kuznetsova, T. V., Kuzmina, S. A., Bobrov, A. A., Tarasov, P. E., Novenko, E. Yu., Meyer, H., Derevyagin, A. Yu., Kienast, F., Bryantseva, A., and Kunitsky, V. V.: Weichselian and Holocene palaeoenvironmental history of the Bol'shoy Lyakhovsky Island, New Siberian Archipelago, Arctic Siberia, Boreas, 38, 72-110. 2009.

Andreev, A. A., Schirrmeister, L., Tarasov, P., Ganopolski, A., Brovkin, V., Siegert, C., and Hubberten, H.-W.: Vegetation and climate history in the Laptev Sea region (arctic Siberia) during Late Quaternary inferred from pollen records, Quaternary Sci. Rev., 30, 2182-2199, 2011.

Andreev, A. A., Morozova, E., Fedorov, G., Schirrmeister, L., Bobrov, A. A., Kienast, F., and Schwamborn, G.: Vegetation history of central Chukotka deduced from permafrost paleoenvironmental records of the El'gygytgyn Impact Crater, Clim. Past, 8, 1287-1300, doi:10.5194/cp-8-1287-2012, 2012.

Baker, A. G., Bhagwar, S., and Willis, K. J.: Do dung fungal spores make a good proxy for past distribution of large herbivores?, Quaternary Sci. Rev., 62, 21-31, 2013.

Ballantyne, A. P., Greenwood, D. R., Sinninghe Damsté, J. S., Csank, A. Z., Eberle, J. J., and Rybczynski, N.: Significantly warmer Arctic surface temperatures during the Pliocene indicated by multiple independent proxies, Geology, 38, 603-606, 2010 . 
Belyi, V. F., Belaya, B. V., and Raikevich, M. I.: Pliocene sediments of the upper stream of the Enmyvaam River and the age of impact genesis of the El'gygytgyn Lake basin, SVKNII, Magadan, 1994 (in Russian).

Brigham-Grette, J., Melles, M., Minyuk, P., Andreev, A., Tarasov, P., DeConto, R., Koenig, S., Nowaczyk, N., Wennrich, V., Rosén, P., Haltia-Hovi, E., Cook, T., Gebhardt, C., Meyer-Jacob, C., Snyder, J., and Herzschuh, U.: Pliocene Warmth, extreme Polar Amplification, and Stepped Pleistocene Cooling recorded in NE Russia, Science, 340, 1421-1427, 2013.

Christensen, J. H., Hewitson, B., Busuioe, A, Chen, A., Gao, X., Held, I., Jones, R., Kwon, W. T., Laprise, R., Rueda, V. M., Mearns, L.O., Menéndez, C. G., Raisanen, J., Rinke, A., Kolli, R. K., Sarr, A., and Whetton, P.: Climate Change 2007: The Physical Science Basis. Contribution of Working Group I to the Fourth Assessment Report of the Intergovernmental Panel on Climate Change, in: Fourth Assessment Report, edited by: Solomon, S., Qin, D., Manning, M., Chen, Z., Marquis, M., Averyt, K. B., Tignor, M., and Miller, H. L., Cambridge University Press, Cambridge and New York, 847-940, 2007.

Clausing, A.: Palaeoenvironmental significance of the green alga Botryococcus in the lacustrine Rotliegend (Upper Carboniferous - Lower Permian), Hist. Biol., 13, 221-234, 1999.

de Schepper, S., Groeneveld, J., Naafs, B. D. A., van Renterghem, C., Hennissen, J., Head, M. J., Louwye, S., and Fabian, K.: Northern Hemisphere Glaciation during the Globally Warm Early Late Pliocene, 8, e81508. doi:10.1371/journal.pone.0081508, 2013.

Demske, D., Mohr, B., and Oberhänsli, H.: Late Pliocene vegetation and climate of the Lake Baikal region, southern East Siberia, reconstructed from palynological data, Palaeogeog. Palaeoclimatol. Palaeoecol., 184, 107-129, 2002.

Dowsett, H. J., Robinson, M., Haywood, A., Salzmann, U., Hill, D., Sohl, L., Chandler, M., Williams, M., Foley, K., and Stoll, D.: The PRISM3D paleoenvironmental reconstruction, Stratigr., 7, 123-139, 2010.

Duk-Rodkin, A., Barendregt, R. W., and White, J. M.: An extensive late Cenozoic terrestrial record of multiple glaciations preserved in the Tintina Trench of west-central Yukon: stratigraphy, paleomagnetism, paleosols, and pollen, Canad. J. Earth Sci., 47, 1003-1028, 2010.

Edwards, M. E., Anderson, P. M., Brubaker, L. B., Ager, T. A., Andreev, A. A., Bigelow, N. H., Cwynar, C. L., Eisner, W. R., Harrison, S. P., Hu, F.-S., Jolly, D., Lozhkin, A. V., MacDonald, G. M., Mock, J., Ritchie, J. C., Sher, A. V., Spear, R. W., Williams, J. W., and Yu, G.: Pollen-based biomes for Beringia 18,000, 6,000 and 0 14C yr B.P., J. Biogeography, 27, 521-555, 2000.

Elias, S. A. and Matthews, J. V.: Arctic North American seasonal temperatures from the latest Miocene to the Early Pleistocene, based on mutual climatic range analysis of fossil beetle assemblages, Canad. J. Earth Sci., 39, 911-920, 2002.

Faith, D. P., Minchin, P. R., and Belbin, L.: Compositional dissimilarity as a robust measure of ecological distance, Plant Ecol., 69, 57-68, 1987.

Fradkina, A. F.: Neogene palynofloras of North-East Asia. Nauka, Moscow, 1983 (in Russian).

Fradkina, A. F.: Palynology of Paleogene and Neogene of NorthEast Asia, in: Palinologiya v SSSR, edited by: Khlonova, A. F., Novosibirsk, Nauka, in Russian, 134-130, 1988.
Fradkina, A. F., Alekseev, M. N., Andreev, A. A., and Klimanov, V. A.: East Siberia, in: Cenozoic climatic and environmental changes in Russia, The Geological Society of America Special Paper 382, 89-103, 2005a.

Fradkina, A. F., Grinenko, O. V., Laukhin, S. A., Nechaev, V. P., Andreev, A. A., and Klimanov, V. A.: Northeastern Asia, in: Cenozoic climatic and environmental changes in Russia, The Geological Society of America Special Paper, 382, 105-120, 2005b.

Giterman, P. E.: Vegetation history of North-East of the USSR. Nauka, Moscow, 1985 (in Russian).

Glushkova, O. Yu. and Smirnov, V. N.: Pliocene to Holocene geomorphic evolution and paleogeography of the El'gygytgyn Lake region, NE Russia, J. Paleolim., 37, 37-47, 2007.

Gorton, H. L. and Vogelmann, T. C.: Ultraviolet radiation and the snow alga Chlamydomonas nivalis (Bauer) Wille, Photochem. Photobiol., 77, 608-615, 2003.

Grinenko, O. V., Sergeenko, A. I., and Belolyubsky, I. N.: Paleogene and Neogene of North-East of Russia. Part 1. Explanatory note to the regional stratigraphic scheme of Paleogene and Neogene sediments in North-East of Russia, Yakutsk Scientific Center of SB RAS, Yakutsk, 1998 (in Russian).

Guy-Ohlson, D.: Botryococcus as an aid in the interpretation of palaeoenvironment and depositional processes. Rev. Palaeobot. Palyn., 71, 1-15, 1992.

Haltia, E. M. and Nowaczyk, N. R.: Magnetostratigraphy of sediments from Lake El'gygytgyn ICDP Site 5011-1: paleomagnetic age constraints for the longest paleoclimate record from the continental Arctic, Clim. Past, 10, 623-642, doi:10.5194/cp-10-6232014, 2014.

Haywood, A. M., Hill, D. J., Dolan, A. M., Otto-Bliesner, B. L., Bragg, F., Chan, W.-L., Chandler, M. A., Contoux, C., Dowsett, H. J., Jost, A., Kamae, Y., Lohmann, G., Lunt, D. J., Abe-Ouchi, A., Pickering, S. J., Ramstein, G., Rosenbloom, N. A., Salzmann, U., Sohl, L., Stepanek, C., Ueda, H., Yan, Q., and Zhang, Z.: Large-scale features of Pliocene climate: results from the Pliocene Model Intercomparison Project, Clim. Past, 9, 191-209, doi:10.5194/cp-9-191-2013, 2013.

Hidy, A. J., Gosse, J. C., Froese, D. G., Bond, J. D., and Rood, D. H.: A latest Pliocene age for the earliest most extensive Cordilleran Ice Sheet in northwestern Canada, Quaternary Sci. Rev., 61, 7784, 2013.

IPCC Fourth Assessment Report: Climate Change: the AR4 Synthesis Report, edited by: Pachauri, R. K., published by: IPCC, Geneva, Switzerland, 2007.

Klaus, W.: "Coccus nivalis". Ein häfiges Microfossil des Spätglazials und frühen Postglazials, Linzer Biol. Beitr., 9, 81-84, 1977.

Klimanov, V. A.: Paleoclimatic reconstruction based on the information statistical method, in: Late Quaternary Environments of the Soviet Union, edited by: Velichko, A. A., Wright, H., and Barnosky, K. W., University of Minnesota, Minneapolis, 297303, 1984.

Kol, E.: Kryobiologie: Biologie und Limnologie des Schnees und Eises I, Kryovegetation. Die Binnengewässer. Einzeldarstellungen aus der Limnologie und ihren Nachbargebieten, Schweizerbartsche Verlagsbuchhandlung Nägele und Obermiller, Stuttgart, 1968. 
Kyshtymov, A. I., Krutous, V. I., Belaya, B. V., and Sadykov, A. R.: Paleogene and Neogene sediments of Arctic and Pacific coasts of Chukotka, in: Continental Paleogene and Neogene of north-east of USSR. Issue I: Arctic and Pacific coasts of Chukotka, Kolyma River basin, edited by: Volobueva, V. I., SVKNII, Magadan, 418, 1988 (in Russian).

Laskar, J., Robutel, P., Joutel, F., Gastineau, M. Correia, A. C. M., and Levrard, B.: A long-term numerical solution for the insolation quantities of the Earth, Astron. Astrophys., 428, 261-285, 2004.

Laukhin, S. A., Klimanov, V. A., and Belaya, B. V.: Late Pliocene and Pleistocene paleoclimates in Northeastern Chukotka, Sbornik Geologickych Ved - Antropozoikum, 23, 17-24, 1999.

Layer, P.: Argon-40/argon-39 age of the El'gygytgyn impact event, Chukotka, Russia, Meteor. Planet. Sci., 35, 591-599, 2000.

Lisiecki, L. E. and Raymo, M. E.: A Pliocene-Pleistocene stack of 57 globally distributed benthic $\delta^{18} \mathrm{O}$ records, Paleoceanography, 20, PA1003, doi:10.1029/2004pa001071, 2005.

Lozhkin, A. V. and Anderson, P. M.: Forest or no forest: implications of the vegetation record for climatic stability in Western Beringia during Oxygen Isotope Stage 3, Quaternary Sci. Rev., 30, 2160-2181, 2011.

Lozhkin, A. V. and Anderson, P. M.: Vegetation responses to interglacial warming in the Arctic: examples from Lake El'gygytgyn, Far East Russian Arctic, Clim. Past, 9, 1211-1219, doi:10.5194/cp-9-1 211-2013, 2013.

Lozhkin, A. V., Anderson, P. M., Matrosova, T. V., and Minyuk, P. S.: The pollen record from El'gygytgyn Lake: implications for vegetation and climate histories of northern Chukotka since the late middle Pleistocene, J. Paleolim., 37, 135-153, 2007.

Matthews, J. V. and Telka, A.: Plant and arthropod fossils, in: Makenzie Delta Borehole Project, edited by: Dallimore, S. R. and Matthews, J. V., Compact discussued by the Geological Survey Canada, 1997.

Matthiessen, J., Knies, J., Vogt, C., and Stein, R.: Pliocene palaeoceanography of the Arctic Ocean and subarctic seas, Philos. Trans. Royal Soc. London A, 367, 21-48, 2009.

Melles, M., Brigham-Grette, J., Minyuk, P., Koeberl, C., Andreev, A., Cook, T., Gebhardt, C, Haltia-Hovi, E., Kukkonen, M., Nowaczyk, N., Schwamborn, G., Wennrich, V., and El'gygytgyn Scientific Party: The Lake El'gygytgyn Scientific Drilling Project - Conquering Arctic Challenges in Continental Drilling, Sci. Drill., 11, 29-40, 2011.

Melles, M., Brigham-Grette, J., Minyuk, P. S., Nowaczyk, N. R., Wennrich, V., DeConto, R. M. Anderson, P. M., Andreev, A., Coletti, A., Cook, T., Haltia-Hovi, E., Kukkonen, Lozhkin, A.V., Rosén, P., Tarasov, P., Vogel, H., and Wagner, B.: 2.8 Million Years of Arctic Climate Change from Lake El'gygytgyn, NE Russia, Science, 337, 315-320, 2012.

Minchin, P. R.: An evaluation of the relative robustness of techniques for ecological ordination, Vegetatio, 69, 89-107, 1987.

Minyuk, P. S., Glushkova, O. Y., Smirnov, V. N., Lozhkin, A. V., Matrosova, T. V., Plyshkevich, A. A., Borkhodoev, V. Y., and Galanin, A. G.: Paleoclimatic data of El'gygytgyn Lake. Information report for 2004-2006, NEISRI FEB RAS, Magadan, 2006 (in Russian).
Moran, K., Backman, J., Brinkhuis, H., Clemens, S.C., Cronin, T., Dickens, G. R., Eynaud, F., Gattacceca, J., Jakobsson, M., Jordan, R. W., Kaminski, M., King, J., Koc, N., Krylov, A., Martinez, N., Matthiessen, J., McInroy, D., Moore, T.C., Onodera, J., O’Regan, M., Pälike, H., Rea, B., Rio, D., Sakamoto, T., Smith, D. C., Stein, R., St John, K., Suto, I., Suzuki, N., Takahashi, K., Watanabe, M., Yamamoto, M., Farrell, J., Frank, M., Kubik, P., Jokat, W., and Kristoffersen, Y.: The Cenozoic palaeoenvironment of the Arctic Ocean, Nature, 441, 601-605, 2006.

Müller, T., Bleiß, W., Martin, C.-D., Rogaschewski, S., and Fuhr, G.: Snow algae from northwest Svalbard: their identification, distribution, pigment and nutrient content, Polar Biol., 20, 14-32, 1998.

NGRIP Members: High-resolution record of Northern Hemisphere climate extending into the last glacial period, Nature, 431, 147151, 2004.

Nowaczyk, N. R., Frederichs, T. W., Kassens, H., NørgaardPedersen, N., Spielhagen, R. F., Stein, R., and Weiel, D.: Sedimentation rates in the Makarov Basin, central Arctic Ocean: A paleomagnetic and rock magnetic approach, Paleoceanography, 16, 368-389, 2001.

Nowaczyk, N. R., Haltia, E. M., Ulbricht, D., Wennrich, V., Sauerbrey, M. A., Rosén, P., Vogel, H., Francke, A., MeyerJacob, C., Andreev, A. A., and Lozhkin, A. V.: Chronology of Lake El'gygytgyn sediments - a combined magnetostratigraphic, palaeoclimatic and orbital tuning study based on multiparameter analyses, Clim. Past, 9, 2413-2432, doi:10.5194/cp-92413-2013, 2013.

Oksanen, J., Blanchet, G. F., Kindt, R., Legendre, P., Minchin, P.R., O’Hara, R. B., Simpson, G. L., Solymos, P., Stevens, M. H. H., and Wagner, H.: Package "vegan". Version 2.0-7, available at: http://vegan.r-forge.r-project.org/, 2013.

Prentice, I. C., Guiot, J., Huntley, B., Jolly, D., and Cheddadi, R.: Reconstructing biomes from palaeoecological data: a general method and its application to European pollen data at 0 and 6 ka, Clim. Dynam., 12, 185-194, 1996.

R Development Core Team: R: A language and environment for statistical computing. R Foundation for Statistical Computing, available at: http://www.R-project.org/, Vienna, Austria, 2011.

Remias, D., Karsten, U., Lütz, C., and Leya, T.: Physiological and morphological processes in the alpine snow alga Chloromonas nivalis (Chlorophyceae) during cyst formation, Protoplasma (D) 243, 73-86, 2010.

Rybczynski, N., Gosse, J. C., Harington, C. R., Wogelius, R. A., Hidy, A. J., and Buckley, M.: Mid-Pliocene warm-period deposits in the High Arctic yield insights into camel evolution, Nat. Commun., 4, 1550, doi:10.1038/ncomms2516, 2013.

Schultze, E.: Neue Erkentnisse zur spät- und frühpostglazialen Vegetations- und Klimaentwicklung im Klagenfurter Becken, Carinthia II, 174, 261-266, 1984.

Schweger, C., Froese, D., White, J. M., and Westgate, J.: Pre-glacial and interglacial pollen records over the last $3 \mathrm{Ma}$ from northwest Canada: Why do Holocene forest differ frpm those of previous interglaciations?, Quaternary Sci. Rev., 30, 2124-2133, 2011.

Sundqvist, H. S., Zhang, Q., Moberg, A., Holmgren, K., Körnich, H., Nilsson, J., and Brattström, G.: Climate change between the mid and late Holocene in northern high latitudes - Part 1: Survey of temperature and precipitation proxy data, Clim. Past, 6, 591608, doi:10.5194/cp-6-591-2010, 2010. 
Tarasov, P. E., Webb III, T., Andreev, A. A., Afanas'eva, N. B., Berezina, N. A., Bezusko, L. G., Blyakharchuk, T. A., Bolikhovskaya, N. S., Cheddadi, R., Chernavskaya, M. M., Chernova, G. M., Dorofeyuk, N. I., Dirksen, V. G., Elina, G. A., Filimonova, L. V., Glebov, F. Z., Guiot, J., Gunova, V. S., Harrison, S. P., Jolly, D., Khomutova, V. I., Kvavadze, E. V., Osipova, I. M., Panova, N. K., Prentice, I. C., Saarse, L., Sevastyanov, D. V., Volkova, V. S., and Zernitskaya, V. P.: Present-day and midHolocene biomes reconstructed from pollen and plant macrofossil data from the former Soviet Union and Mongolia, J. Biogeography, 25, 1029-1053, 1998.

Tarasov, P. E., Volkova, V. S., Webb III, T., Guiot, J., Andreev, A. A., Bezusko, L. G., Bezusko, T. V., Bykova, G. V., Dorofeyuk, N. I., Kvavadze, E. V., Osipova, I. M., Panova, N. K., and Sevastyanov, D. V.: Last Glacial Maximum biomes reconstructed from pollen and plant macrofossil data from Northern Eurasia, J. Biogeography, 27, 609-620, 2000.

Tarasov, P., Granoszewski, W., Bezrukova, E., Brewer, S., Nita, M., Abzaeva, A., and Oberhänsli, H.: Quantitative reconstruction of the Last Interglacial vegetation and climate based on the pollen record from Lake Baikal, Russia, Clim. Dynam., 25, 625-637, 2005.

Tarasov, P. E., Andreev, A. A., Anderson, P. M., Lozhkin, A. V., Leipe, C., Haltia, E., Nowaczyk, N. R., Wennrich, V., BrighamGrette, J., and Melles, M.: A pollen-based biome reconstruction over the last 3.562 million years in the Far East Russian Arctic - new insights into climate-vegetation relationships at the regional scale, Clim. Past, 9, 2759-2775, doi:10.5194/cp-9-27592013, 2013.
Ukraintseva, V. V., Sokolov, V. T., Kuzmin, S. B., and Visnevskiy, A. A.: Investigation of snow cover and an air of atmosphere in vicinities of North Pole using the pollen analysis method, Polar Geogr., 32, 143-152, 2009.

van den Hoek, C., Mann, D., and Jahns, H. M.: Algae: an introduction to phycology, Cambridge University Press, Cambridge, 1995.

van Geel, B.: Non-pollen palynomorphs, in: Tracking environmental change using lake sediments, Vol. 3: Terrestrial, algal and silicaceous indicators, edited by: Smol, J. P., Birks, H. J. B., Last, W. M., Bradley, R. S., and Alverson, K., Kluwer, Dordrecht, 99119, 2001.

Vasil'chuk, A. S. and Vasil'chuk, Yu. K.: Local pollen spectra as a new criterion for non-glacier origin of massive ice, Doklady Earth Sci., 433, 985-990, 2009.

Vasil'chuk, A. S. and Vasil'chuk, Yu. K.: Comparison of pollen spectra from massive and glacial ices for cryogenetic indication, Kriosfera Zemli, 14, 15-28, 2010 (in Russian).

Volobueva, V. I., Belaya, B. V., Plovova, T. P., and Narkhinova, V. E.: Marine and continental and Neogene of north-east of USSR, in: Issue 2: Paleocene, edited by: Pokhlalainen, V. P., SVKNII, Magadan, 1990 (in Russian).

White, J. M., Ager, T. A., Adam, D. M., Leopold, E. B., Liu, G., Jette, H., and Schweger, C. E.: An 18 million record of vegetation and climate change in northwestern Canada and Alaska: tectonic and global climatic correlations. Palaeogeog., Palaeoclimatol., Palaeoecol., 130, 293-306, 1997. 